\title{
Current and Future Immunomodulation Strategies to Restore Tolerance in Autoimmune Diseases
}

\author{
Jeffrey A. Bluestone and Hélène Bour-Jordan \\ UCSF Diabetes Center, University of California at San Francisco, San Francisco, California 94143 \\ Correspondence: Jeff.Bluestone@ucsf.edu
}

Autoimmune diseases reflect a breakdown in self-tolerance that results from defects in thymic deletion of potentially autoreactive T cells (central tolerance) and in T-cell intrinsic and extrinsic mechanisms that normally control potentially autoreactive T cells in the periphery (peripheral tolerance). The mechanisms leading to autoimmune diseases are multifactorial and depend on a complex combination of genetic, epigenetic, molecular, and cellular elements that result in pathogenic inflammatory responses in peripheral tissues driven by self-antigen-specific T cells. In this article, we describe the different checkpoints of tolerance that are defective in autoimmune diseases as well as specific events in the autoimmune response which represent therapeutic opportunities to restore long-term tolerance in autoimmune diseases. We present evidence for the role of different pathways in animal models and the therapeutic strategies targeting these pathways in clinical trials in autoimmune diseases.

\begin{abstract}
Atoimmune diseases are debilitating conditions that affect a large and growing portion of the population $(\sim 3 \%-5 \%$ in the United States) (Jacobson et al. 1997). Autoimmune diseases take a devastating toll on affected families and have a considerable economic impact. Thus, improving the understanding of autoimmune diseases and developing novel therapies have been significant goals in public health. The development of autoimmune diseases reflects a loss of tolerance of the immune system for self-antigens. With the exception of a few rare monogenic diseases such as immune dysreg-
\end{abstract}

ulation, polyendocrinopathy, enteropathy, Xlinked syndrome (IPEX), and autoimmune polyendocrinopathy-candidiasis-ectodermal dystrophy (APECED) syndrome, the development of autoimmunity is a complex and multifactorial process. This process usually involves genetic predispositions and poorly defined environmental factors that result in slight alterations in many different checkpoints, which in turn tilts the balance toward autoreactivity and away from immunoregulation. Although clearly there are key roles for B cells, antigen-presenting cells (APCs), and the innate immune response in

Editors: Diane J. Mathis and Alexander Y. Rudensky

Additional Perspectives on Immune Tolerance available at www.cshperspectives.org

Copyright (C) 2012 Cold Spring Harbor Laboratory Press; all rights reserved; doi: 10.1101/cshperspect.a007542

Cite this article as Cold Spring Harb Perspect Biol 2012;4:a007542 
J.A. Bluestone and H. Bour-Jordan

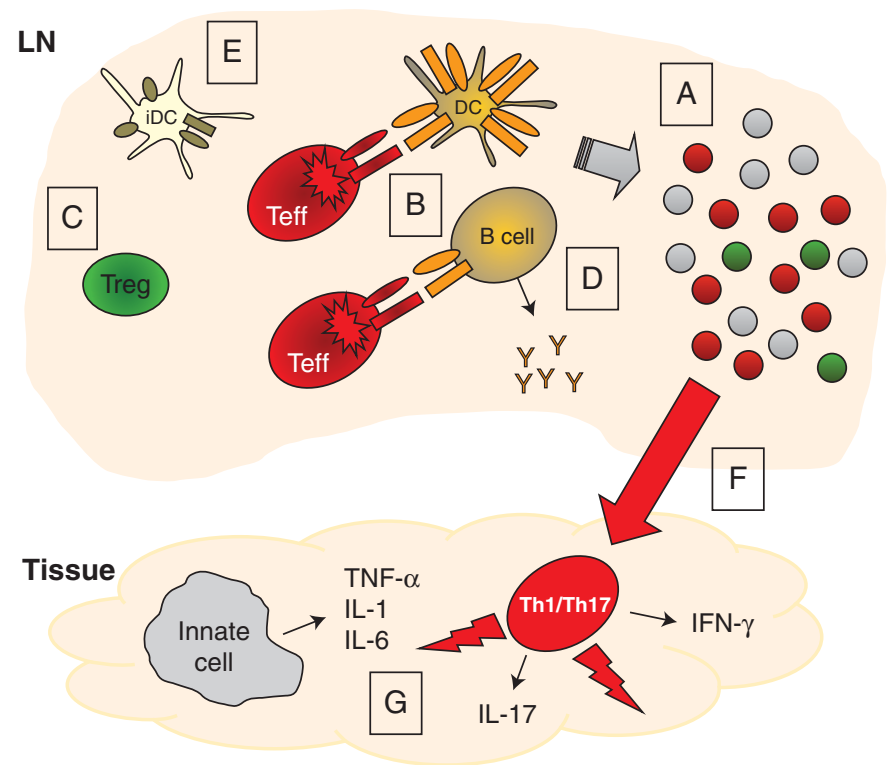

Figure 1. Development of the pathogenic autoimmune response and targets for immunotherapy. Autoreactive $\mathrm{T}$ cells that escape thymic negative selection are usually controlled by intrinsic (inhibitory receptors) and extrinsic (regulatory cell populations) mechanisms of tolerance in the periphery. In individuals genetically prone to autoimmunity, one or several of these checkpoints are defective, resulting in expansion of autoreactive $\mathrm{T}$ cells that cannot be controlled by Tregs (red, autoreactive effector T cells; green, Tregs; gray, polyclonal conventional $\mathrm{T}$ cells). Autoreactive $\mathrm{T}$ cells migrate to their targeted tissue where cytotoxic mechanisms and uncontrolled inflammation mediated by soluble mediators released by $\mathrm{T}$ cells and innate cells result in tissue damage. Various immunotherapeutic strategies target different steps in this process. (A) The ultimate goal of immunotherapy is to alter the balance of pathogenic versus regulatory $\mathrm{T}$ cells to restore tolerance, as detailed in Figure 2. (B) Anti-CD3 mAbs, antigen-specific therapies, and costimulation blockade alter the interactions between autoreactive T cells and antigen-presenting cells (APCs) and/or the signaling pathways resulting from productive T-cell receptor (TCR) ligation after presentation of cognate self-peptide/MHC (major histocompatibility complexes) in the presence of costimulatory signals, leading to deletion, anergy, immune deviation, or induction of Tregs. (C) Many strategies aim at boosting Tregs, either by concomitantly deleting Teff and promoting Tregs, and thus resetting the immune system to various degrees, such as antithymocyte globulin (ATG), rapamycin plus IL-2, and autologous hematopoietic stem cell transplantation (HSCT), or directly providing Tregs through cellular therapy. $(D, E)$ Some therapies target populations of APCs, such as depletion of B cells by rituximab or the promotion of self-antigen presentation specifically by tolerogenic dendritic cells (DCs). (F) The migration of autoreactive T cells to their target tissue is being altered by inhibitors of leukocyte trafficking such as natalizumab and fingolimod. These drugs may further promote tolerance by keeping autoreactive T cells in the lymph nodes (LN) during immunosuppression, a prerequisite for efficient immunomodulation in some cases. $(G)$ Anti-inflammatory therapies such as tumor necrosis factor (TNF) antagonists reduce tissue damage but also create an immunological environment more favorable to the induction of Tregs and restoration of tolerance.

the development and progression of autoimmune diseases, this article will focus on autoreactive $\mathrm{T}$ cells and potential targets of tolerogenic treatments (Fig. 1). In addition, we will discuss selected strategies currently available or being developed in the clinic as well as future opportunities to prevent and treat these diseases. Finally, current clinical strategies available as the standard of care for autoimmune diseases rely on immunosuppressive and anti-inflammatory treatments that curtail the pathological events, alleviate symptoms, and provide short-term relief in some patients. Thus, we will focus for the most part on 
immunotherapies aimed at reestablishing longterm tolerance.

\section{PATHOGENESIS OF AUTOIMMUNE DISEASES AND POTENTIAL TARGETS FOR REESTABLISHING IMMUNE TOLERANCE}

Different checkpoints are in place to ensure immune tolerance to self-antigens and prevent damage to tissues (Goodnow et al. 2005). Many potentially autoreactive T-cell receptors (TCRs) are excluded in central lymphoid organs by $\mathrm{V}(\mathrm{D}) \mathrm{J}$ recombination and deletion/cell death in the thymus and periphery. These mechanisms generally aim at eliminating cells with high affinity for self-antigens, although thymocytes with a repertoire skewed toward autoreactivity may actually be selected into the $\mathrm{CD} 4{ }^{+}$Foxp $^{+}{ }^{+}$regulatory T-cell (Treg) lineage. Thymocytes are selected by recognition of peptide-major histocompatibility complex (MHC) complexes presented on specialized APCs. The predominant association of given $\mathrm{MHC}$ haplotypes with susceptibility or resistance to many autoimmune diseases in both mice and humans, including type 1 diabetes (T1D), multiple sclerosis (MS), and rheumatoid arthritis (RA) (Wellcome Trust Case Control 2007), illustrates the importance of this process. Additionally, the autoimmune regulator (Aire) protein is crucial for the expression and presentation of tissue-specific antigens by medullary thymic epithelial cells (mTECs) during negative selection of potentially autoreactive thymocytes (Anderson et al. 2002). Negative selection of autoreactive $\mathrm{T}$ cells in the thymus is governed by quantitative factors such as the level of expression of self-antigens and intensity of TCR signaling as well as qualitative parameters such as the molecular nature of selecting peptide/MHC complexes. Furthermore, the molecular intricacies of self-antigen presentation in the thymus and periphery greatly influence the fate of autoreactive T cells (Stadinski et al. 2010a).

Many $\mathrm{T}$ cells with potentially autoreactive receptors escape thymic selection and can be readily detected in healthy individuals, which requires the existence of powerful mechanisms to control these autoreactive $\mathrm{T}$ cells and maintain peripheral tolerance in the majority of the population. Autoreactive T cells can be controlled by intrinsic and extrinsic mechanisms. Intrinsic control of autoreactive $\mathrm{T}$ cells is regulated by a complex network of costimulatory and inhibitory molecules that have differential effects on T-cell activation, expansion, migration, and effector function (Bour-Jordan et al. 2011). To be efficiently activated, $T$ cells need to receive a "signal 1" provided by the TCR on recognition of cognate peptide/MHC complexes and a "signal 2" provided by costimulatory molecules such as CD28. Defective costimulation prevents T-cell activation and can lead to unresponsiveness, making it an attractive therapeutic strategy that is actively pursued in autoimmune diseases through blockade of costimulatory pathways or administration of selfantigens in the context of suboptimal costimulation. Inhibitory receptors such as cytotoxic Tlymphocyte antigen-4 (CTLA-4 or CD152) and programmed death-1 (PD-1 or CD279) exert a nonredundant intrinsic control on autoreactive $\mathrm{T}$ cells and are critical for the maintenance of peripheral tolerance (Fife and Bluestone 2008). Another important aspect of the autoimmune response is the migration of autoreactive T cells and trafficking into their target tissues. These processes are regulated by cell-surface molecules including integrins, selectins, chemokine receptors, and sphingosine-1-phosphate receptors and numerous therapies already approved or in clinical trials for autoimmune diseases target these pathways (Yopp et al. 2004). Finally, both $\mathrm{CD}^{+}$and $\mathrm{CD} 8^{+} \mathrm{T}$ cells have been shown to mediate autoimmune diseases, and the tissue damage inherent to autoimmunity can be mediated by a range of proinflammatory cytokines produced by innate cells or T cells (McFarland and Martin 2007; Bluestone et al. 2010). Thus, immunotherapies currently in development are targeting proinflammatory cytokines and other mediators of inflammation. Besides improving clinical parameters on administration, some of these approaches may promote long-term tolerance by dampening the inflammatory milieu that is deleterious for immunoregulatory mechanisms (Koulmanda and Strom 2010). 
In addition to intrinsic control of autoreactive $\mathrm{T}$ cells, specialized suppressor cell populations (including regulatory B cells, dendritic cell [DC] subsets, other innate cells, and T-cell subsets) are crucial to maintain peripheral tolerance and prevent autoimmunity. Tregs control autoreactive $\mathrm{T}$ cells in the periphery (Wing and Sakaguchi 2010). Thymically derived $\mathrm{CD}^{+}$ CD25 ${ }^{+}$T cells, often referred to as natural Tregs (nTregs), express the lineage-specific transcription factor Foxp3. Fatal multiorgan autoimmunity develops in "scurfy" mice or IPEX patients that have deficiency or loss-of-function mutations in the Foxp3 gene (Fontenot et al. 2003). In humans, many autoimmune diseases are associated with a lower frequency of circulating Tregs and alterations in suppressive function or molecular pathways that regulate Treg biology (Brusko et al. 2008). Additionally, several immune genes that have been identified as susceptibility alleles for autoimmune diseases, such as CTLA-4, IL-2, CD25, or PTPN22, are involved in pathways important for Treg homeostasis and function (Maier and Hafler 2009). Thus, many molecules that control conventional $\mathrm{T}$ cells are also expressed on Tregs and have important biological relevance for this subset. Tregs have a unique and highly robust therapeutic profile: Although the requirement for specific TCR-mediated activation limits Treg suppressive activity to the site or lymph node (LN) of interest, their effector function appears to work by bystander suppression and infectious tolerance and results in the regulation of local inflammatory responses through a combination of cell-cell contact and suppressive cytokine production (Tang and Bluestone 2008). Among their mechanisms of action, immunoregulatory cytokines transforming growth factor- $\beta$ (TGF$\beta)$, IL-10, and IL-35 have been shown to participate in Treg suppressive function and direct contacts of Tregs with DCs are also important for Treg-mediated regulation through pathways involving interactions of CTLA-4 on Tregs with B7 on APCs. When measurable, increases in these parameters may represent surrogate read-outs for the efficiency of immunomodulatory treatments in restoring immunoregulation and peripheral tolerance.

\section{SYSTEMIC IMMUNOTHERAPIES TO RESTORE THE BALANCE OF PATHOGENIC VERSUS REGULATORY CELLS}

Autoimmunity stems from an imbalance in pathogenic versus regulatory cell populations that result from defects in both populations. Thus, therapies targeting the $\mathrm{T}$-cell compartment will likely be most efficacious at restoring tolerance if they influence the balance by concomitantly reducing the pathogenic T-cell population and enhancing the numbers or function of suppressive pathways (Fig. 2). Several strategies that affect $\mathrm{T}$ cells in a systemic manner are being developed to achieve this goal and have shown promising results in clinical trials. Two related reagents known as antilymphocyte serum (ALS) and antithymocyte globulin (ATG) target polyclonal $\mathrm{T}$ cells nonspecifically and result in massive but transient T-cell deletion (van de Linde et al. 2006). In the nonobese diabetic (NOD) model, ATG efficiently reverted disease in new-onset diabetic mice, possibly owing to preferential reconstitution of the peripheral T-cell compartment by Tregs (Simon et al. 2008). In humans, in addition to depletion of conventional T cells, ATG has been shown to expand Treg populations both by conversion of $\mathrm{CD} 4{ }^{+} \mathrm{CD} 25^{-}$cells into Tregs and, to a lesser degree, proliferation of nTregs (Lopez et al. 2006; Feng et al. 2008), supporting a potential tolerogenic profile for ATG therapy in autoimmune diseases. A clinical trial of ATG in a small number of T1D patients was beneficial for preservation of islet function but accompanied by side effects associated with a "cytokine storm" (Saudek et al. 2004). A phase II trial supported by the immune tolerance network is currently underway to determine the effects of a different dosing protocol of ATG in T1D, with the hope of reducing side effects while preserving or maximizing the clinical benefits. The immune tolerance network (ITN-www.immunetolerance.org) is an international consortium created with the goal of achieving clinical tolerance in autoimmunity, transplantation, allergy, and asthma, and it has sponsored many clinical trials of various tolerogenic treatments in autoimmune 


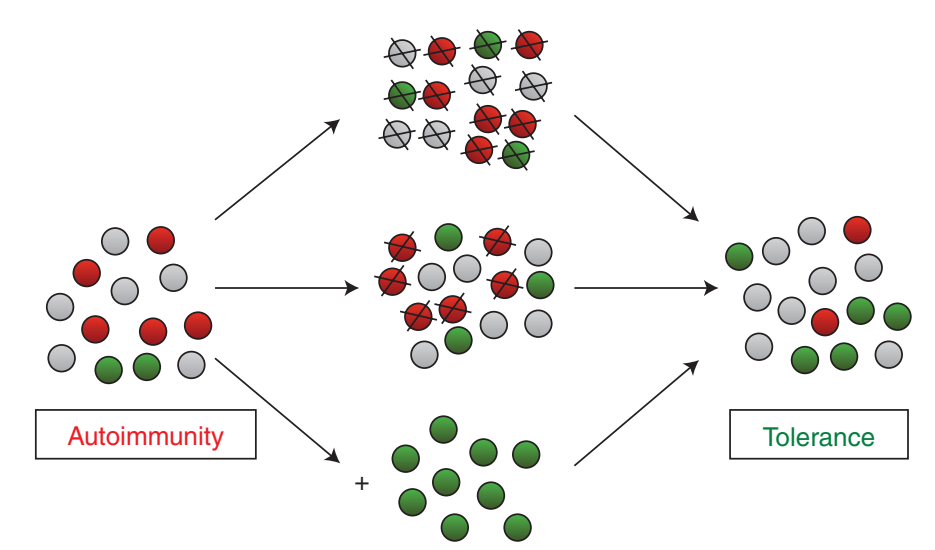

Figure 2. Restoration of tolerance at the population level. To restore tolerance, immunotherapy must invert the balance of effector and regulatory $\mathrm{T}$ cells by decreasing the number of pathogenic autoreactive $\mathrm{T}$ cells, increasing the number of Tregs, or both. Several therapies are aiming for this unique goal via distinct strategies. Systemic therapies such as ATG, autologous HSCT, rapamycin plus IL-2, and anti-CD3 mAbs affect most T cells but induce alterations in T-cell subsets and repertoire that result in a reduced Teff:Treg ratio (top). A similar end result is achieved by antigen-specific therapy by depletion of autoreactive T cells only (middle). Finally, Treg cellular therapy aims at restoring a tolerogenic Teff:Treg balance by directly increasing the number of Tregs.

diseases, some of which are described in this article.

The anti-CD3 antibody OKT3 was the first FDA-approved $\mathrm{mAb}$ with initial applications in transplantation. In the NOD model, anti-CD3 $\mathrm{mAbs}$ restored normoglycemia in new-onset diabetic mice, generating interest in using this strategy in humans (Chatenoud et al. 1997). Second-generation FcR-nonbinding (FNB) reagents have been developed and FNB anti-CD3 treatment was efficacious at reversing diabetes in NOD mice and ameliorating disease in the MS model, experimental autoimmune encephalomyelitis (EAE) (Kohm et al. 2005). In humans, humanized FNB mAb OKT3 $\gamma 1$ ala-ala (teplizumab) retained the beneficial effect of OKT3 on renal transplantation without the deleterious cytokine storm side effect (Woodle et al. 1999). Treatment of T1D patients with a short course (12-14 d) of teplizumab within 6 wk of diagnosis significantly reduced the loss of C-peptide for up to $2 \mathrm{yr}$ but ultimately could not maintain the residual $\beta$-cell function (Herold et al. 2002, 2009). Similar results were obtained using another FNB anti-CD3 mAb called ChAglyCD3 (otelixizumab) (Keymeulen et al. 2005). Nevertheless, the observation of clinical benefits that lasted much longer than the short course of treatment suggested that FNB antiCD3 mAbs may have tolerogenic properties, and an ITN-sponsored phase II clinical trial is underway in T1D patients to determine whether $\beta$-cell function will be prolonged by administration of a second course of teplizumab after $13 \mathrm{mo}$. Teplizumab is also being evaluated in clinical trials for psoriasis and psoriatic arthritis. Teplizumab does not significantly deplete $\mathrm{T}$ cells but may have tolerogenic properties owing to altered TCR signaling, although the mechanisms underlying the efficacy of teplizumab in humans are still not fully defined. In mice, FNB anti-CD3 mAbs preferentially induce deletion and anergy of effector $\mathrm{T}$ cells (Teff), in particular, potentially pathogenic Th1 cells, whereas $\mathrm{CD} 4{ }^{+}$Tregs are preserved, resulting in a shift in the Teff:Treg ratio (Belghith et al. 2003; Penaranda et al. 2011). FNB anti-CD3 mAbs also increased expression of the transcription factor Helios (originally described as a marker for more stable nTregs) on remaining Tregs, suggesting that treatment may alter the Treg transcriptome and possibly favor the stability of the Treg lineage, an important point given recent concerns about the instability of a subset of Tregs that may be associated with autoimmunity in mice and humans (Zhou et al. 2009; 
Dominguez-Villar et al. 2011; McClymont et al. 2011). In T1D patients, teplizumab treatment in T1D patients has been associated with the induction of a putative regulatory population of $\mathrm{CD} 8{ }^{+}$Foxp $^{+}$cells and an increase ratio of IL-10 to IFN- $\gamma$ production, which is compatible with increased immunoregulation (Herold et al. 2003). Additionally, a recent study in humanized mice and T1D patients suggested that teplizumab induced gut tropic CD $4^{+}$Foxp $3^{+}$CCR $6{ }^{+}$ Tregs, which produced IL-10 on migration to the gut and subsequently returned to the circulation (Waldron-Lynch et al. 2012). Finally, oral administration of low doses of the "classical" form of anti-CD3 mAbs efficiently suppressed active forms of EAE, autoimmune diabetes, and other autoimmune diseases in mice without the toxicity associated with IV injection, possibly owing to the induction of $\mathrm{CD} 4^{+} \mathrm{CD} 25^{-}$ $\mathrm{LAP}^{+}$Th3 suppressor cells in gut-associated tissues (Ochi et al. 2006). These encouraging data have prompted the initiation of clinical trials of oral OKT3, currently for the treatment of active ulcerative colitis.

IL-2 plays a central role in the expansion and survival of $\mathrm{CD}^{+}$and $\mathrm{CD}^{+}$antigen-specific effector and memory T cells. However, IL-2 is also critical to support the development, survival, and suppressive function of Tregs (Cheng et al. 2011). Thus, the fatal multiorgan autoimmune disease that develops in mice deficient in IL-2, and in mice or humans with deficient IL-2-receptor (IL-2R) chains, is primarily owing to a defective Treg compartment (Malek et al. 2002). In autoimmune diabetes, deficient IL-2 production by effector $\mathrm{T}$ cells locally in pancreatic islets and suboptimal IL-2 signaling in Tregs have been described in NOD mice and T1D patients, respectively, and may contribute to the loss of peripheral tolerance and development of autoimmunity (Tang et al. 2008; Long et al. 2010). Thus, the IL-2 pathway is an attractive target for immunomodulation of autoimmune diseases aiming at restoring effective Treg-mediated tolerance but proper dosing protocols will have to be carefully evaluated, particularly in view of preclinical murine studies showing that low-dose versus high-dose IL-2 therapy may preferentially induce a relative in- crease in Tregs versus Teff populations, respectively (Boyman et al. 2006; Tang et al. 2008). Alternatively, IL-2 may be combined with therapies targeting pathogenic $\mathrm{T}$ cells. Rapamycin (Sirolimus and its analog Temsirolimus) is an mTOR inhibitor that selectively inhibits Teff proliferation, notably in the Th1 and Th17 subsets (Delgoffe et al. 2011). Importantly, rapamycin has been shown to promote Treg survival and function and results in a relative enrichment in Tregs in mice and humans (Battaglia et al. 2005; Delgoffe et al. 2009). Rapamycin is being extensively developed in transplantation owing to its tolerogenic profile and clinical trials are also underway in MS and systemic lupus erythematosus (SLE). Treatment with rapamycin was previously shown to increase Treg function in a small number of T1D patients (Monti et al. 2008). In NOD mice, a combination of rapamycin and IL-2 afforded long-term protection against diabetes (Rabinovitch et al. 2002). A phase I trial sponsored by the ITN and designed to restore the balance of effector and regulatory $\mathrm{T}$ cells in $\mathrm{T} 1 \mathrm{D}$ by administration of rapamycin and IL-2 recently concluded with encouraging results (Long et al. 2012). In this trial, new-onset diabetic patients treated with rapamycin plus IL-2 displayed a transient increase in Treg frequency and a stable restoration of STAT5 phosphorylation on IL-2 signaling in Tregs, which is defective in T1D patients (Long et al. 2010). Unfortunately, patients displayed a dramatic increase in natural killer $(\mathrm{NK})$ cells and a transient decrease in $\beta$-cell function. Thus, although IL-2 therapy may have beneficial consequences on Tregs, its effects on NK cells and the relative inefficiency of rapamycin in this trial highlighted the necessity to better define the primary target of treatment and design alternative strategies to selectively expand Tregs.

Several systemic therapies that are not directly targeting $\mathrm{T}$ cells have shown efficiency and tolerogenic properties in T-cell-mediated autoimmune diseases. B cells are critical for the presentation of self-antigens and production of autoantibodies, and depleting B cells reduced disease in preclinical models of T1D and MS (Hu et al. 2007; Monson et al. 2011). 
Many clinical trials of the B-cell-depleting drug rituximab are currently underway in a variety of autoimmune diseases, including prototypical T-cell-mediated diseases such as T1D and MS. Phase II and III clinical trials in RA, MS, and T1D have shown promising results and a potentially tolerogenic effect of rituximab as evidenced by improvement of disease for almost a year with a short-course treatment with rituximab (Edwards et al. 2004; Hauser et al. 2008; Pescovitz et al. 2009). Combination of rituximab with methotrexate or administration of two courses of rituximab showed improved efficacy in RA (Tak et al. 2011). The mechanisms underlying the efficacy and tolerogenic potential of rituximab in autoimmune diseases are not well defined. In mouse models expressing a human CD20 transgene, improvement of T1D and EAE was associated with the induction of regulatory cell populations, including myeloidderived suppressor cells (MDSCs) and Tregs, and reduced responsiveness of self-antigen-specific Teff (Monson et al. 2011; Hu et al. 2012). Finally, intravenous immunoglobulins (IVIG) may promote tolerance in autoimmune diseases. IVIG are therapeutic preparations of normal human polyclonal IgG purified from large donor plasma pools and they are widely used for the treatment of autoimmunity and inflammation. IVIG therapy has shown clinical benefits and is currently in phase II/III clinical trials in several autoimmune diseases, including relapsing-remitting MS (RRMS), myasthenia gravis, and T-cell-mediated peripheral neuropathies Guillain-Barré syndrome and chronic inflammatory demyelinating polyneuropathy (CIDP) (Arnson et al. 2009). Long-term IVIG therapy consists of recurrent high doses but the efficacy of maintenance therapy with lower doses or treatment discontinuation has not been evaluated. The modes of action of IVIG are not completely understood but they are complex and involve immunoregulation of various cell types and molecular pathways (Nimmerjahn and Ravetch 2008). IVIG contain natural antibodies with reactivity to T-cell-surface molecules such as TCR and CD4, and IVIG has been shown to inhibit T-cell activation and proliferation either directly or indirectly through modulation of DC function (Bayry et al. 2003; MacMillan et al. 2009). Importantly, recent reports have shown that IVIG could bind human Tregs and promoted Treg-mediated suppression via mechanisms that may include $\mathrm{F}\left(\mathrm{ab}^{\prime}\right)_{2}$-dependent direct stimulation of Tregs and activation of Tregs by Treg-specific MHC class II-restricted epitopes ("Tregitopes") from the Fc fragment of IgG (Kessel et al. 2007; De Groot et al. 2008; Tha-In et al. 2010). In mice, IVIG treatment induced the expansion of nTregs in vivo and afforded protection from EAE or allograft rejection in a Treg-dependent manner (Ephrem et al. 2008; Tha-In et al. 2010). Thus, IVIG may have tolerogenic properties that are worth pursuing clinically in autoimmune diseases, notably in combination with B-cell-depletion strategies given the primary indication of IVIG as an immunoglobulin replacement therapy.

\section{ANTIGEN-SPECIFIC IMMUNOTHERAPY}

Antigen-specific tolerogenic therapies are appealing from a safety point of view because they are not expected to induce global immunosuppression like systemic approaches. Conversely, it is still not clear whether induction of tolerance to a small number of dominant selfantigens will efficiently control autoimmunity after epitope spreading has occurred. Encouraging results from animal models have shown that induction of tolerance to a single self-antigen can efficiently thwart a polyclonal autoreactive response owing to mechanisms of "bystander suppression" and dominant antigen nonspecific immunoregulation (Tang et al. 2004; Tarbell et al. 2004; Fife et al. 2006). Another potential caveat for antigen-specific therapy consists in the difficulty in choosing the appropriate protein or peptide in view of recent reports showing that the molecular intricacies of self-antigen presentation related to the unique flexibility of certain self-peptides to bind to certain MHC class II molecules could greatly affect the generation and activation of autoreactive $\mathrm{T}$ cells. As an example, I-A ${ }^{\mathrm{g} 7}$, the only class II allele expressed in the nonobese diabetic (NOD) mouse, a spontaneous model for multiple autoimmune 
diseases, is essential for the development of autoimmunity (Wicker et al. 1995). Determination of the crystal structure of peptide/MHC complexes uncovered that the binding groove of I-A $\mathrm{A}^{\mathrm{g} 7}$, the only class II allele and strongest susceptibility gene for diabetes in NOD mice, as well as of the highly disease-associated HLADQ8 in humans, is distinct from other MHC class II molecules at both terminal ends and is thus permissive for unique peptide-MHC structural interactions (Corper et al. 2000; Latek et al. 2000). Insulin is a key autoantigen in T1D in humans and NOD mice, and a peptide from the insulin $\beta$ chain (B:9-23) is a major target of autoreactive $\mathrm{CD} 4^{+} \mathrm{T}$ cells (Zhang et al. 2008). This peptide can bind the peptide-binding groove of $\mathrm{I}-\mathrm{A}^{\mathrm{g} 7}$ molecules in at least three overlapping adjacent positions (or "registers"), and B:9-23 peptide registers may be distinct in the thymus and pancreas (Levisetti et al. 2007; Stadinski et al. 2010c). Discrete T-cell populations have been identified that recognize the insulin peptide in each register (Mohan et al. 2010, 2011; Crawford et al. 2011). A subset of T cells recognizes a register generated by intracellular processing of insulin by APCs in the thymus and periphery, and these $\mathrm{T}$ cells are efficiently deleted in the thymus, whereas distinct peptidebinding registers may be generated from soluble peptides present in vesicles of APCs in the pancreas. This finding may help to explain how self-reactive $T$ cells specific for insulin peptides can escape thymic negative selection. Similarly, dominant epitopes of self-antigens chromogranin A in T1D and myelin basic protein (MBP) in MS and EAE bind the peptide-binding groove in an unusual register that would have been predicted to result in very poor binding or no binding (He et al. 2002; Stadinski et al. 2010b). Importantly, TCRs from MBP-specific T cells in MS patients have been shown to interact with MBP peptides bound to MHC class II molecules in a very unusual position ( $\mathrm{Li}$ et al. 2005), suggesting that self-antigenic peptides may be recognized in atypical registers in humans as well. Other mechanisms have been described for the generation of new epitopes specifically in peripheral tissues or conditions of local inflammation and may contribute to the escape of autoreactive $\mathrm{T}$ cells from thymic deletion and their activation in the periphery in RA, celiac disease, MS, and T1D (Anderton 2004; Goverman 2011). These recent advances have tremendous implications for the design of antigenspecific immunotherapies and may explain the disappointing results obtained in clinical trials to date.

Several approaches have been used to induce tolerance to self-antigens in preclinical models. Oral or nasal administration of soluble self-antigens efficiently prevented several autoimmune diseases in animal models, including EAE and colitis, through mucosal tolerance pathways of anergy, deletion, or induction of TGF- $\beta$ - or IL10-producing Tregs (Karpus et al. 1996). However, attenuation or reversal of ongoing disease has been less successful (Kennedy et al. 1997; Bai et al. 1998). High-dose tolerance achieved by intravenous injection of soluble peptides or DNA vaccination has shown some success in mouse models of T1D (Coon et al. 1999), but anaphylactic responses and exacerbation of disease have also been observed in the NOD mouse and EAE models (Weaver et al. 2001; Smith et al. 2005), raising concerns about the safety of this approach in patients. Altered peptide ligands (APLs) are derived from dominant peptides driving the autoimmune response and modified to alter interactions with autoreactive TCRs, thus functioning as antagonists or partial agonists of T-cell signaling (Nicholson and Kuchroo 1997). APLs of myelin epitopes and the clinically relevant APL glatiramer acetate prevent and reverse disease in EAE models, through immune deviation of Th1 or Th17 responses to Th2 responses and a role of immunosuppressive cytokines TGF- $\beta$ and IL-10 (Nicholson et al. 1995; Maron et al. 2002). Finally, it was recently shown that nanoparticles coated with complexes of MHC class I molecules bound to peptides from self-antigens insulin or islet-specific glucose-6-phosphatase catalytic subunit-related protein (IGRP) could reverse disease in NOD mice and in a humanized model of T1D through the expansion of autoreactive regulatory $\mathrm{CD} 8^{+} \mathrm{T}$ cells that are naturally generated during the autoimmune process (Tsai et al. 2010). 
In humans, antigen-specific therapies have been evaluated in clinical trials in MS and T1D patients. In MS, antigen-specific approaches usually target myelin antigens MBP, proteolipid protein (PLP), and myelin oligodendrocyte glycoprotein (MOG), which are believed to be major targets of the T- and B-cell response. Results from a phase III study evaluating the efficacy of intravenous injection of MBP8298, an MBP peptide containing immunodominant $\mathrm{T}$ - and B-cell epitopes in HLA-DR2 patients, in secondary progressive MS showed no clinical benefit compared with placebo (Freedman et al. 2011). Phase I/II trials of DNA vaccination with full-length MBP in secondary progressive and relapsing-remitting MS showed decreased myelin-specific T-cell responses and autoantibodies but no significant improvement of clinical parameters (Bar-Or et al. 2007; Garren et al. 2008). Clinical trials using APLs of the immunodominant MBP epitope yielded mixed results. Adverse effects including exacerbation of disease and hypersensitivity reactions were observed with high doses of APLs and halted one of the trials out of safety concerns (Bielekova et al. 2000; Kappos et al. 2000). However, some improvement was observed in patients receiving the lower doses of APLs. The APL glatiramer acetate, a random mixture of amino acids glutamine, lysine, alanine, and tyrosine peptides of various lengths, did not provide any significant benefit in primary progressive MS but showed some efficacy in reducing the frequency of relapses and decreasing disability progression in RRMS, and it is FDA approved for this indication (Wolinsky et al. 2007; Ford et al. 2010).

A number of autoantigens have been characterized in T1D patients, including insulin, GAD65, and IGRP (Bluestone et al. 2010). Insulin has been used for immunotherapy in newly diagnosed patients and prevention studies. Several phase I and II trials were performed in new-onset diabetic patients using oral insulin or NBI-6024, an APL for the dominant 9-23 insulin B chain epitope, with no clinical efficacy (Chaillous 2000; Walter et al. 2009). In the Diabetes Prevention Trial-Type 1 Diabetes (DPT1) study, relatives of T1D patients positive for islet-cell autoantibodies and deemed at relatively high risk for developing disease were treated with IV plus subcutaneous (sc) or oral insulin therapy and followed for the diagnosis of diabetes (DPT-1-Diabetes-Study-Group 2002). Insulin therapy did not delay or prevent diabetes in the DPT-1 study, with the exception of some clinical benefits in a subgroup with high levels of anti-insulin autoantibodies. A new trial is ongoing to specifically test insulin therapy in this subpopulation. A large prevention trial of intranasal insulin in at-risk individuals also showed no effect on the onset of diabetes (Nanto-Salonen et al. 2008). Antigen therapy using alum-formulated GAD65 (GAD-alum) in newly diagnosed T1D patients was recently shown in a phase III trial to have no effect on the decline in stimulated C-peptide levels or any other secondary outcome despite some encouraging results in previous phase II trials (Wherrett et al. 2011; Ludvigsson et al. 2012). Finally, the most promising results for antigen therapy in T1D thus far have been obtained in recently diagnosed patients after sc administration of DiaPep277, a peptide from the heat shock protein HSP60, which injection preserves islet-cell function in NOD mice (Elias and Cohen 1996). Phase I/II trials showed that DiaPep277 therapy was safe but had no clinical benefit in children (Lazar et al. 2007). In adults, DiaPep277 was shown in phase II trials to have some effects on preservation of C-peptide levels but no accompanying benefits on HbA1c levels or insulin requirements (Raz et al. 2007; Schloot et al. 2007). Two multicenter phase III trials are currently underway.

Overall, antigen-specific immunotherapy for the prevention or treatment of autoimmune diseases has been largely disappointing and failed to reproduce the efficacy observed in preclinical animal models and small human clinical trials. This may reflect the fact that antigen therapy in humans occurs in the context of a more complex immunological environment and higher exposure to proinflammatory signals compared with laboratory animals. Additionally, it has been shown in T1D patients receiving pancreas transplantation that effector and memory autoreactive $\mathrm{T}$ cells may be resistant to deletion 
or suppression, suggesting that antigen therapy may need to be combined with systemic approaches to eliminate memory populations before antigen administration (Laughlin et al. 2008; Vendrame et al. 2010). Finally, the presence of unique peptide registers specifically in tissues suggests that the cognate peptides involved in activation of autoreactive T cells in the periphery may have to be identified to develop efficacious antigen therapy.

\section{IMMUNOMODULATION OF T-CELL COSTIMULATION, MIGRATION, AND INFLAMMATION}

Immunotherapies targeting costimulatory and migration pathways have been developed with the rationale that they may preferentially target pathogenic $T$ cells during an active autoimmune disease. The costimulatory molecule CD28 is expressed on $\mathrm{T}$ cells and its interaction with B7-1 and B7-2 is critical for many aspects of T-cell activation and effector function (Salomon and Bluestone 2001). Importantly, blocking CD28/B7 interactions during TCR signaling can result in tolerance mediated by T-cell deletion and/or anergy, which is particularly relevant from a therapeutic point of view to restore tolerance in autoimmune diseases (Bluestone et al. 2006). In mouse models, blockade of CD28 signaling using a CTLA4Ig fusion protein was extremely effective at controlling many autoimmune diseases including MS and SLE (Scalapino and Daikh 2008). The central role of CD28 in Treg homeostasis also led to the unexpected observation that treatment with CTLA4Ig significantly depleted Tregs and exacerbated diabetes in NOD mice (Salomon et al. 2000), emphasizing that immunomodulation of costimulatory pathways can adversely affect the balance of effector versus regulatory $\mathrm{T}$ cells in the context of a given immune response and local environment. CTLA4Ig (abatacept or the higher-affinity second-generation variant belatacept) has shown an $>50 \%$ response rate in psoriasis and RA patients resistant to TNF- $\alpha$-blocking therapy and is FDA approved for RA and (JIA) (Abrams et al. 1999; Genovese et al. 2005). In contrast, abatacept failed to reduce disease flares in a phase II clinical trial in SLE patients also receiving oral corticosteroids, and a phase III trial in Crohn's disease was terminated early owing to a lack of efficacy (Merrill et al. 2010). In a recent multicenter trial in newly diagnosed T1D patients, treatment with abatacept for 2 years was well tolerated and delayed the reduction in $\beta$-cell function compared with placebo (Orban et al. 2011). However, the decrease in C-peptide levels with abatacept was parallel to that with placebo after 6 months of treatment, suggesting that the progression of disease became independent of CD28-dependent T-cell activation a few months after diagnosis and before the complete loss of $\beta$-cell function. Thus, the efficacy of CTLA4Ig in autoimmune diseases may be limited to CD28-dependent phases of disease, which could reflect the fact that some T cells are not as dependent on CD28 costimulation as naïve $\mathrm{CD} 4^{+} \mathrm{T}$ cells, notably memory $\mathrm{T}$ cells and $\mathrm{CD} 8^{+} \mathrm{T}$ cells. Clinical trials of abatacept and belatacept are presently underway in MS, SLE, and T1D. Current regimen of CTLA4Ig did not result in widespread immunosuppression or increased rates of infection, a clear benefit in the treatment of autoimmune diseases. Additionally, analysis of kidney allograft recipients treated with belatacept showed no long-term difference in the number of Tregs (Bluestone et al. 2008). These results contrast with murine studies, perhaps owing to a lower dosing regimen in humans that may preferentially affect Teff over Tregs. Should concerns arise about Treg homeostasis after CTLA-4-Ig treatment in future trials, single blockade of B7-2 may be considered as an alternative because it was most efficient at reducing the activation of autoreactive $\mathrm{T}$ cells while minimally affecting the Treg compartment (BourJordan et al. 2004; Bour-Jordan and Bluestone 2009).

Alefacept is an LFA-3-Ig fusion protein that blocks the interaction of LFA-3 on APCs with costimulatory molecule CD2 on T cells. Alefacept has shown efficacy in reducing lesions in a phase III trial of patients with psoriasis and is currently FDA approved for this indication (Sugiyama et al. 2008). Alefacept is being evaluated in an ITN-sponsored phase II trial in patients 
with new-onset T1D. Basiliximab and daclizumab are two similar mAbs targeting the highaffinity $\alpha$ chain of the IL-2 receptor, CD25. Daclizumab reduced the number of lesions and improved the clinical scores in RRMS either as an adjunct therapy to IFN- $\beta$ or in patients' refractory to IFN- $\beta$ treatment (Bielekova et al. 2009; Wynn et al. 2010). Importantly, CD25 blockade prevents expansion of alloreactive $\mathrm{T}$ cells in transplantation but also leads to Treg depletion and widespread autoimmunity in mice. Reduction in both frequency and function of Tregs has been observed after basiliximab and daclizumab treatment (Bluestone et al. 2008; Oh et al. 2009), raising concerns about the use of these reagents in immunotherapies designed to restore immune tolerance. Finally, interactions of CD154 (aka CD40L) on T cells and CD40 on APCs are important for the stimulation of autoreactive $\mathrm{T}$ cells, activation of APCs, and production of autoantibodies (Grewal and Flavell 1996). Therapeutic blockade of this pathway held tremendous promise in the 1990s owing to its high efficacy and tolerogenic potential in preclinical models of autoimmune diseases and transplantation (Law and Grewal 2009). Clinical trials of anti-CD154 monoclonal antibodies (mAbs) were initiated in several autoimmune diseases including SLE, Crohn's disease, psoriasis, and MS but had to be halted owing to an unexpectedly high number of thromboembolic events. Novel antagonistic reagents are being developed against CD40 and CD154 to avoid these adverse effects and if their safety profile is adequate, they will undoubtedly be tested as part of the therapeutic arsenal to restore tolerance in autoimmune diseases.

Another class of immunomodulatory agents targets molecular pathways involved in leukocyte migration to the peripheral tissues affected by the autoimmune response. Importantly, although some of these therapies are primarily preventing the migration of pathogenic $\mathrm{T}$ cells to the site of inflammation, others, alone or in combination with other immunosuppressive drugs, have tolerogenic properties that may be related to the role of anatomic localization of antigen presentation in the outcome of T-cell priming versus unre- sponsiveness (Yopp et al. 2004). Indeed, T-cell homing to the LNs is required for the generation of antigen-specific Tregs and induction of peripheral tolerance after immunotherapy in murine models of transplantation (Bai et al. 2002; Ochando et al. 2005). Thus, T-cell trafficking and LN occupancy during systemic immunosuppression are crucial determinants for the induction and maintenance of tolerance. As a consequence, immunotherapies targeting T-cell migration in autoimmune diseases could be key components of combinatorial approaches to promote homing of autoreactive $\mathrm{T}$ cells to LNs and their tolerization during immunosuppression. For example, in stringent mouse models of transplantation, anti-LFA-1 monotherapy was not tolerogenic but combination with anti-CD154 or anti-ICAM-1 mAbs synergistically induced donor-specific tolerance (Nicolls and Gill 2006). Anti-integrin mAbs natalizumab (against the $\alpha 4$ subunit of $\alpha 4 \beta 1$ and $\alpha 4 \beta 7$ integrins) and efalizumab (anti-LFA-1) are among the most successful drugs designed for cell-trafficking blockade, with indications in RRMS, Crohn's disease, and psoriasis (Dubertret et al. 2006; Ransohoff 2007; Targan et al. 2007). Natalizumab reduced the rate of relapses and progression of disability in RRMS and increased rates of remission in Crohn's disease. Unfortunately, cases of progressive multifocal leukoencephalopathy (PML) were associated with treatment, resulting in additional label warning for natalizumab and voluntary withdrawal of efalizumab by the manufacturer (Hartung 2009). Natalizumab is FDA approved in RRMS and Crohn's disease for patients with severe disease or disease refractory to other standard treatments, but concerns remain about the safety profile of this drug.

Remarkable clinical results have been obtained after treatment with fingolimod (FTY7 20), a small compound affecting T-cell trafficking by interfering with the sphingosine pathway, which is critical for lymphocyte egress from the thymus and peripheral lymphoid organs (Matloubian et al. 2004). Indeed, fingolimod results in down-regulation of S1P receptors and lymphocyte sequestration in lymphoid organs (Mandala et al. 2002), and it efficiently prevented or 
attenuated disease in NOD mice, EAE, collageninduced arthritis, and colitis (Webb et al. 2004; Maki et al. 2005). In phase III trials in RRMS patients, fingolimod improved the relapse rate and disability progression after 1 to 2 years as compared with placebo and even standard therapy, IFN- $\beta$ (Cohen et al. 2010; Kappos et al. 2010). Fingolimod thus became the first oral therapy approved for the treatment of MS. However, adverse effects associated with fingolimod therapy were significant and reflected its systemic immunosuppressive properties. Second-generation reagents targeting the sphingosine pathway are being developed with possibly reduced side effects (Bagdanoff et al. 2010). Clinical trials of fingolimod and second-generation drugs are being conducted for several autoimmune diseases. The mechanisms of action of FTY720 are still unclear. FTY720 has been suggested to induce T-cell apoptosis and to increase Treg numbers and function (Sawicka et al. 2005; Daniel et al. 2007). In NOD mice, treatment with FTY720 at a time of significant insulitis prevented diabetes by sequestering $\mathrm{T}$ cells into tertiary lymphoid organs (TLOs) in the pancreas, but treatment withdrawal resulted in a rapid loss of TLO integrity and development of diabetes (Penaranda et al. 2010). Thus, despite its clinical benefits, fingolimod monotherapy may not be efficacious beyond the duration of treatment, and combination of fingolimod with immunosuppressive therapies that promote immunoregulation within the LNs may be optimal to restore long-term tolerance. In this regard, FTY720 plus antigen therapy, but not FTY720 alone, efficiently suppressed disease on discontinuation of treatment in an EAE model (Yoshida et al. 2011).

Finally, there is a renewed interest in immunotherapies targeting proinflammatory cytokines or other mediators of inflammation in autoimmune diseases, not only to improve clinical parameters but also to restore tolerance. Indeed, in addition to inducing tissue damage, proinflammatory mediators may be a barrier to the restoration of tolerance by altering the balance of pathogenic versus immunoregulatory cell populations, in particular at the site of inflammation, owing to their role in the differ- entiation and stability of T-cell subsets (Hanidziar and Koulmanda 2010). For example, several TNF- $\alpha$ antagonists are currently approved in autoimmune diseases, including RA, psoriasis, and Crohn's disease and they may have tolerogenic properties (Sfikakis 2010). Increased spontaneous apoptosis and defective suppressive function have been described in Tregs isolated from RA patients. Anti-TNF- $\alpha$ therapy has been shown to increase Treg numbers, reduce Treg apoptosis to normal levels, and restore suppressive function (Ehrenstein et al. 2004; Toubi et al. 2005). Both Treg defects and their reversal by TNF antagonists correlated with increased or decreased disease activity, respectively. Of note, this tolerogenic effect of anti-TNF therapy was related to the TGF- $\beta$-dependent induction of peripheral Tregs, which compensated for the defective nTreg population in RA patients (Nadkarni et al. 2007).

\section{CELLULAR THERAPIES TO RESTORE TOLERANCE IN AUTOIMMUNE DISEASES}

Several strategies for cellular therapy effectively prevented disease and restored tolerance in preclinical models of autoimmune diseases and are now being developed for clinical applications. Following the observation that allogeneic hematopoietic stem cell transplantation (HSCT) implemented for malignancies could have beneficial effects on coincidental autoimmune diseases, HSCT has been performed in hundreds of patients suffering from severe autoimmune conditions refractory to conventional treatments (Burt et al. 2008). ATG is often used as a conditioning reagent in conjunction with cyclophosphamide in nonmyeloablative autologous HSCT in autoimmune diseases. In mice, syngeneic bone-marrow transplantation induced remission from EAE and new-onset diabetes (Karussis et al. 1993; Wen et al. 2008). In humans, autologous nonmyeloablative HSCT has shown spectacular benefits in many patients, with long-term stabilization, amelioration or remission from disease in $>50 \%$ of immunotherapy-refractory patients with MS, SLE, systemic sclerosis, and small cohorts of patients with T1D and Crohn's disease (Craig et al. 2003; 
Oyama et al. 2007; Couri et al. 2009; Illei et al. 2011). In contrast, autologous HSCT resulted in increased relapse rates in RA (Verburg et al. 2005). Currently, conditioning treatment toxicity and transplant-related mortality preclude the generalization of autologous HSCT to the general population of autoimmune patients. However, improvements in treatment regimens and completion of more rigorous clinical trials may result in a better definition of the most relevant clinical applications with the highest benefit to risk ratio. Mechanistically, studies in mouse models and patients with autoimmune diseases have led to the hypothesis that autologous HSCT restores tolerance to self-antigens. The initial conditioning regimen of cyclophosphamide and ATG eliminates autoreactive T cells as well as long-lived autoantibody-producing plasma cells (Zand et al. 2005; Alexander et al. 2009). The subsequent autologous HSCT increases thymic output and results in the generation of a novel T-cell repertoire and an increased number of Tregs (Farge et al. 2005; Muraro et al. 2005; Roord et al. 2008). Thus, autologous HSCT may allow the development of a novel immune system, perhaps in the context of different environmental and immunological conditions, in which immunoregulation may again be dominant in responses to self-antigens except in patients in which the genetic propensity to autoimmunity is too high. Finally, there is a growing interest in mesenchymal stem cells (MSCs), also called multipotent mesenchymal stromal cells, for the treatment of autoimmune diseases (Tyndall 2011). MSCs are stromally derived adult progenitor cells that can be obtained from various tissues, including bone marrow (BM), placenta, umbilical cord, and fat. The original interest in MSCs stemmed from their ability to transdifferentiate into other tissues and potentially induce tissue "regeneration," but their primary clinical application in autoimmune diseases is now related to their immunomodulatory properties (Kode et al. 2009). MSCs have effectively restored tolerance in animal models of autoimmunity, and a large number of clinical trials in autoimmune diseases, including MS, Crohn's disease, and SLE, have been initiated and are currently underway
(Tyndall and Uccelli 2009). The mechanisms underlying their tolerogenic effects are not clear but may be mediated by both cell-cell contacts and soluble factors such as TGF- $\beta$, 2,3-indoleamine dioxygenase (IDO), and soluble HLA-G. Although MSCs represent a promising tolerogenic therapy for autoimmune diseases, many challenges remain for their clinical applications, in particular, in the standardization of the source and preparation of MSCs, which may affect their potency in patients.

Several therapeutic approaches take advantage of the long-term T-cell unresponsiveness induced by various forms of tolerogenic APCs. Induction of tolerance using antigen-coupled ethylene carbodiimide (ECDI)-fixed cells is a potent strategy that has been used successfully to prevent and reverse disease using insulincoupled cells in NOD mice and MBP- and PLP-coupled cells in EAE (Vandenbark et al. 1996; Fife et al. 2006). In EAE, ECDI-fixed cells coupled to myelin peptides were significantly safer and more effective at curbing disease than soluble peptides (Smith et al. 2005). ECDI-fixed cells coupled to IGRP prevented the development of disease in a humanized model of diabetes (Niens et al. 2011). The mechanisms are not fully elucidated, but altered interactions of tolerized T cells with APCs, TCR signaling defects, intrinsic control by CTLA- 4 and PD-1, and extrinsic regulation by Tregs may all be involved (Eagar et al. 2002; Fife et al. 2006, 2009). A clinical trial sponsored by the ITN is in final stages of development to evaluate the safety and efficacy of autologous peripheral blood leukocytes (PBLs) ECDI-coupled with a mixture of immunodominant epitopes from MBP, PLP, and MOG in patients with RRMS. Additionally, a clinical trial of insulin-coupled autologous PBMCs is currently being developed by the ITN for T1D patients. Other valuable approaches rely on the injection or targeting of tolerogenic DCs in autoimmune diseases (Hilkens et al. 2010). Several different populations of tolerogenic DCs have been described, including immature DCs in steady state that can become stimulatory after maturation and specialized populations of DCs that specifically promote regulatory cell populations even in conditions 
of inflammation, such as plasmacytoid DCs (pDCs) (Steinman et al. 2003). Subsets of DCs express distinct cell-surface markers that have been exploited to target self-antigens selectively to tolerogenic DCs using complexes of self-antigen and $\mathrm{mAbs}$ specific for appropriate markers such as DEC-205 and Siglec-H, resulting in antigen-specific T-cell unresponsiveness and reduction of autoimmunity in mouse models (Bonifaz et al. 2002; Petzold et al. 2010; Loschko et al. 2011). Additionally, DCs can be manipulated ex vivo to retain an immature phenotype and induce tolerance in vivo. Administration of immature DCs has shown efficacy in murine models, and phase I studies to determine the safety of autologous tolerogenic DC therapy have been initiated in T1D and RA (Machen et al. 2004; Harry et al. 2010).

Altering the Treg compartment, by depleting Tregs or interfering with molecular pathways necessary for their homeostasis or function, uniformly exacerbated autoimmune responses, whereas promoting Treg-mediated suppression has successfully prevented and reversed autoimmune diseases in models of T1D, MS, SLE, IBD, and others (Kohm et al. 2002; Mottet et al. 2003; Tang et al. 2004; Scalapino et al. 2006). Despite the therapeutic efficacy of Tregs in animal models, clinical studies of adoptive immunotherapy with Tregs in autoimmune diseases have been lacking. We have initiated the first U.S. clinical trial of Treg cellular therapy in patients with T1D (ClinicalTrials.gov Identifier NCT01210664). The study is a phase I safety trial of adult T1D patients within 2 years of diagnosis and is sponsored by the Juvenile Diabetes Research Foundation (JDRF). $\mathrm{CD}^{+}{ }_{-}^{-}$ $\mathrm{CD} 25^{+} \mathrm{CD} 127^{\mathrm{lo} /-}$ Tregs will be purified from T1D patients (Liu et al. 2006) and expanded in vitro using an optimized protocol (Putnam et al. 2009) to increase the number of Tregs to therapeutically relevant levels and possibly improve their suppressive function (Tang et al. 2004; Chai et al. 2008). Escalating cell doses will then be infused back into each patient in an autologous manner to assess the safety and feasibility of Treg therapy. Possible risks associated with any polyclonal Treg therapy include adverse events related to immunosuppression, such as increased infections and malignancies, and to the possible instability of a fraction of Tregs that may result in acceleration of disease (McClymont et al. 2011). However, these events are unlikely considering the relatively low number of Tregs administered as compared with the endogenous population. Importantly, it was recently shown in the first clinical trial using Treg therapy in humans that infusion of expanded Tregs with the goal of improving graft versus host disease (GVHD) had no deleterious side effects and reduced the incidence of moderate to severe GVHD without affecting the graft-versus-leukemia effect (Brunstein et al. 2011). Thus, if safe and successful, Treg cellular therapy may revolutionize the approach to immunomodulation of autoimmune diseases.

The future use of Treg therapy in autoimmune diseases may be determined by the ability to develop antigen-specific Treg immunotherapy. Indeed, antigen-specific Tregs derived from either TCR transgenic ( $\mathrm{Tg}$ ) mice or endogenous antigen-specific $\mathrm{T}$ cells were more potent than polyclonal Tregs at suppressing autoimmunity (Tang et al. 2004; Masteller et al. 2005). The challenge in translating these findings to the treatment of autoimmune diseases lies in the isolation of sufficient quantities of antigen-specific $\mathrm{T}$ cells - a challenge that is not easily overcome in human patients (Brusko et al. 2008). Even when reagents are available to specifically label antigen-specific $\mathrm{T}$ cells (for example, via peptide-MHC multimer staining), efforts to expand endogenous self-antigen-reactive Tregs have been mostly unsuccessful. Novel strategies are being developed to circumvent these limitations and engineer Tregs with self-antigen specificity in vitro by introducing TCR genes of given specificity into polyclonal Treg populations using lentiviral or retroviral vectors. $\mathrm{Hu}-$ man polyclonal Tregs engineered to express a TCR specific for the melanoma antigen tyrosinase could be successfully expanded in vitro and retained their ability to suppress tyrosinase-specific and bystander T-cell responses (Brusko et al. 2010). Similarly engineered murine Tregs could suppress antitumor responses in vivo. Additionally, murine polyclonal Tregs transduced with a TCR specific for a single model self- 
antigen could efficiently suppress disease in murine models of colitis and arthritis (Elinav et al. 2009; Wright et al. 2009). Nevertheless, the potential of viral vectors to induce cellular transformation leading to leukemia have remained major concerns for the public and regulatory bodies. Additional safety concerns raised by the introduction of TCR chains include the generation of adverse specificities by mispairing of the transduced and endogenous TCR chains, although novel molecular strategies are specifically designed to avoid this complication (Govers et al. 2010). The expectation is that infused Tregs do not need to be long lived and will result in the induction of endogenous Tregs capable of maintaining long-term suppression thanks to mechanisms of "infectious tolerance." Thus, engineered Tregs could include the cotransduction of "suicide genes" together with TCR chains, to allow the deletion of the injected cells and their progeny if needed (Guillot-Delost et al. 2008).

\section{CONCLUDING REMARKS}

Considerable progress has been made in the immunomodulation of autoimmune diseases and the understanding of the complex molecular and cellular pathways targeted by novel treatments. Despite the realization that the translation of effective therapies from animal models to patients is often difficult to achieve, a number of immunotherapies have become the standard of care and greatly improved the clinical outcome and quality of life of patients with some autoimmune diseases. Potential new targets are constantly being identified in animal models of autoimmune diseases and the generation of humanized models may be critical to better predict if results of preclinical models will translate to humans. Among the novel approaches being pursued, clinical trials address the "hygiene hypothesis" by testing whether stimulation of the immune system with parasitic worms or bacterial extracts could ameliorate autoimmune diseases (Alyanakian et al. 2006; Fleming et al. 2011). Small molecules targeting intracellular mediators of signaling in $\mathrm{T}$ cells or other cell populations have shown efficacy in preclinical models of autoimmune diseases and several are being developed for clinical trials in T1D, Crohn's disease, RA, and MS (Louvet et al. 2008; Burli et al. 2010). Encouraging results have been obtained with inhibitors of JAK tyrosine kinases (Coombs et al. 2010; Fridman et al. 2010; Punwani et al. 2012). Therapies targeting the epigenetic regulation of immune responses may gain prominence in the future. Drugs targeting DNA methylation and chromatin remodeling (notably histone deacetylase [HDAC] inhibitors) are already in use in cancer and have shown tolerogenic properties in murine models of transplantation (Tao et al. 2007), and RNA silencing agents (siRNAs, miRNAs, antagomirs, etc.) are generating a lot of interest (Rigby and Vinuesa 2008). Finally, it is likely that immunomodulation of autoimmune diseases will require combinatorial therapy to truly restore long-term tolerance and abrogate disease, either by combining immunotherapies with approaches for tissue regeneration or by targeting two or more pathways to synergistically repair the different components of the autoimmune imbalance.

\section{ACKNOWLEDGMENTS}

The authors would like to thank members of the Bluestone laboratory for their scientific contributions and many discussions that have helped to move this article and field along. In addition, the authors want to thank especially Lukas Jeker, Mark Anderson, and Abul Abbas for critical reading of the manuscript. Finally, the authors thank the National Institutes of Health, The Juvenile Diabetes Research Foundation, and many philanthropic donors who have supported the work over the years.

\section{REFERENCES}

Abrams JR, Lebwohl MG, Guzzo CA, Jegasothy BV, Goldfarb MT, Goffe BS, Menter A, Lowe NJ, Krueger G, Brown MJ, et al. 1999. CTLA4Ig-mediated blockade of Tcell costimulation in patients with psoriasis vulgaris. J Clin Invest 103: 1243.

Alexander T, Thiel A, Rosen O, Massenkeil G, Sattler A, Kohler S, Mei H, Radtke H, Gromnica-Ihle E, Burmester GR, et al. 2009. Depletion of autoreactive immunologic memory followed by autologous hematopoietic stem cell transplantation in patients with refractory SLE 
J.A. Bluestone and H. Bour-Jordan

induces long-term remission through de novo generation of a juvenile and tolerant immune system. Blood 113: 214-223.

Alyanakian MA, Grela F, Aumeunier A, Chiavaroli C, Gouarin C, Bardel E, Normier G, Chatenoud L, Thieblemont N, Bach JF. 2006. Transforming growth factor- $\beta$ and natural killer T-cells are involved in the protective effect of a bacterial extract on type 1 diabetes. Diabetes 55: 179-185.

Anderson MS, Venanzi ES, Klein L, Chen Z, Berzins SP, Turley SJ, von Boehmer H, Bronson R, Dierich A, Benoist C, et al. 2002. Projection of an immunological self shadow within the thymus by the aire protein. Science 298: $1395-1401$.

Anderton SM. 2004. Post-translational modifications of self antigens: Implications for autoimmunity. Curr Opin Immunol 16: 753-758.

Arnson Y, Shoenfeld Y, Amital H. 2009. Intravenous immunoglobulin therapy for autoimmune diseases. Autoimmunity 42: 553-560.

Bagdanoff JT, Donoviel MS, Nouraldeen A, Carlsen M, Jessop TC, Tarver J, Aleem S, Dong L, Zhang H, Boteju L, et al. 2010. Inhibition of sphingosine 1-phosphate lyase for the treatment of rheumatoid arthritis: Discovery of (E)-1-(4-((1R,2S,3R)-1,2,3,4-tetrahydroxybutyl)-1H-imidazol-2-yl)ethanone oxime (LX2931) and (1R,2S,3R)-1-(2-(isoxazol-3-yl)-1H-imidazol-4-yl)butane-1,2,3,4-tetraol (LX2932). J Med Chem 53: 86508662.

Bai XF, Li HL, Shi FD, Liu JQ, Xiao BG, Van der Meide PH, Link H. 1998. Complexities of applying nasal tolerance induction as a therapy for ongoing relapsing experimental autoimmune encephalomyelitis (EAE) in DA rats. Clin Exp Immunol 111: 205-210.

Bai Y, Liu J, Wang Y, Honig S, Qin L, Boros P, Bromberg JS. 2002. L-Selectin-dependent lymphoid occupancy is required to induce alloantigen-specific tolerance. J Immunol 168: 1579-1589.

Bar-Or A, Vollmer T, Antel J, Arnold DL, Bodner CA, Campagnolo D, Gianettoni J, Jalili F, Kachuck N, Lapierre Y, et al. 2007. Induction of antigen-specific tolerance in multiple sclerosis after immunization with DNA encoding myelin basic protein in a randomized, placebo-controlled phase 1/2 trial. Arch Neurol 64: 1407-1415.

Battaglia M, Stabilini A, Roncarolo MG. 2005. Rapamycin selectively expands $\mathrm{CD} 4^{+} \mathrm{CD} 25^{+} \mathrm{FoxP}^{+}$regulatory $\mathrm{T}$ cells. Blood 105: 4743-4748.

Bayry J, Lacroix-Desmazes S, Carbonneil C, Misra N, Donkova V, Pashov A, Chevailler A, Mouthon L, Weill B, Bruneval P, et al. 2003. Inhibition of maturation and function of dendritic cells by intravenous immunoglobulin. Blood 101: 758-765.

Belghith M, Bluestone JA, Barriot S, Megret J, Bach JF, Chatenoud L. 2003. TGF- $\beta$-dependent mechanisms mediate restoration of self-tolerance induced by antibodies to CD3 in overt autoimmune diabetes. Nat Med 9: 12021208.

Bielekova B, Goodwin B, Richert N, Cortese I, Kondo T, Afshar G, Gran B, Eaton J, Antel J, Frank JA, et al. 2000. Encephalitogenic potential of the myelin basic protein peptide (amino acids 83-99) in multiple sclerosis: Re- sults of a phase II clinical trial with an altered peptide ligand. Nat Med 6: 1167-1175.

Bielekova B, Howard T, Packer AN, Richert N, Blevins G, Ohayon J, Waldmann TA, McFarland HF, Martin R. 2009. Effect of anti-CD25 antibody daclizumab in the inhibition of inflammation and stabilization of disease progression in multiple sclerosis. Arch Neurol 66: 483489.

Bluestone JA, St Clair EW, Turka LA. 2006. CTLA4Ig: Bridging the basic immunology with clinical application. Immunity 24: 233-238.

Bluestone JA, Liu W, Yabu JM, Laszik ZG, Putnam A, Belingheri M, Gross DM, Townsend RM, Vincenti F. 2008. The effect of costimulatory and interleukin 2 receptor blockade on regulatory $\mathrm{T}$ cells in renal transplantation. Am J Transplant 8: 2086-2096.

Bluestone JA, Herold K, Eisenbarth G. 2010. Genetics, pathogenesis and clinical interventions in type 1 diabetes. Aug 17 464: $1293-1300$.

Bonifaz L, Bonnyay D, Mahnke K, Rivera M, Nussenzweig MC, Steinman RM. 2002. Efficient targeting of protein antigen to the dendritic cell receptor DEC205 in the steady state leads to antigen presentation on major histocompatibility complex class I products and peripheral $\mathrm{CD}^{+} \mathrm{T}$ cell tolerance. J Exp Med 196: $1627-1638$.

Bour-Jordan H, Bluestone JA. 2009. Regulating the regulators: Costimulatory signals control the homeostasis and function of regulatory T cells. Immunol Rev 229: 41-66.

Bour-Jordan H, Salomon BL, Thompson HL, Szot GL, Bernhard MR, Bluestone JA. 2004. Costimulation controls diabetes by altering the balance of pathogenic and regulatory T cells. J Clin Invest 114: 979-987.

Bour-Jordan H, Esensten JH, Martinez-Llordella M, Penaranda C, Stumpf M, Bluestone JA. 2011. Intrinsic and extrinsic control of peripheral T-cell tolerance by costimulatory molecules of the CD28 / B7 family. Immunol Rev 241: 180-205.

Boyman O, Kovar M, Rubinstein MP, Surh CD, Sprent J. 2006. Selective stimulation of T cell subsets with antibody-cytokine immune complexes. Science 311: 19241927.

Brunstein CG, Miller JS, Cao Q, McKenna DH, Hippen KL, Curtsinger J, Defor T, Levine BL, June CH, Rubinstein P, et al. 2011. Infusion of ex vivo expanded $T$ regulatory cells in adults transplanted with umbilical cord blood: Safety profile and detection kinetics. Blood 117: 1061-1070.

Brusko TM, Putnam AL, Bluestone JA. 2008. Human regulatory T cells: Role in autoimmune disease and therapeutic opportunities. Immunol Rev 223: 371-390.

Brusko TM, Koya RC, Zhu S, Lee MR, Putnam AL, McClymont SA, Nishimura MI, Han S, Chang LJ, Atkinson MA, et al. 2010. Human antigen-specific regulatory $\mathrm{T}$ cells generated by $\mathrm{T}$ cell receptor gene transfer. PloS ONE 5: e11726.

Burli RW, Haughan AF, Hodges AJ. 2010. Development of small-molecule therapies for autoimmune diseases. $A u$ toimmunity 43: 526-538.

Burt RK, Testori A, Craig R, Cohen B, Suffit R, Barr W. 2008. Hematopoietic stem cell transplantation for 
autoimmune diseases: What have we learned? J Autoimmun 30: 116-120.

Chai JG, Coe D, Chen D, Simpson E, Dyson J, Scott D. 2008. In vitro expansion improves in vivo regulation by $\mathrm{CD} 4{ }^{+} \mathrm{CD} 25^{+}$regulatory $\mathrm{T}$ cells. J Immunol $\mathbf{1 8 0}$ : $858-869$.

Chaillous L. 2000. Oral insulin administration and residual $\beta$-cell function in recent-onset type 1 diabetes: A multicentre randomised controlled trial. Diabete Insuline Orale group. Lancet 356: 545-549.

Chatenoud L, Primo J, Bach JF. 1997. CD3 antibody-induced dominant self tolerance in overtly diabetic NOD mice. J Immunol 158: 2947-2954.

Cheng G, Yu A, Malek TR. 2011. T-cell tolerance and the multi-functional role of IL-2R signaling in T-regulatory cells. Immunol Rev 241: 63-76.

Cohen JA, Barkhof F, Comi G, Hartung HP, Khatri BO, Montalban X, Pelletier J, Capra R, Gallo P, Izquierdo G, et al. 2010. Oral fingolimod or intramuscular interferon for relapsing multiple sclerosis. N Engl J Med 362: 402415.

Coombs JH, Bloom BJ, Breedveld FC, Fletcher MP, Gruben D, Kremer JM, Burgos-Vargas R, Wilkinson B, Zerbini CA, Zwillich SH. 2010. Improved pain, physical functioning and health status in patients with rheumatoid arthritis treated with CP-690,550, an orally active Janus kinase (JAK) inhibitor: Results from a randomised, double-blind, placebo-controlled trial. Ann Rheum Dis 69: $413-416$.

Coon B, An LL, Whitton JL, von Herrath MG. 1999. DNA immunization to prevent autoimmune diabetes. J Clin Invest 104: 189-194.

Corper AL, Stratmann T, Apostolopoulos V, Scott CA, Garcia KC, Kang AS, Wilson IA, Teyton L. 2000. A structural framework for deciphering the link between I-Ag7 and autoimmune diabetes. Science 288: 505-511.

Couri CE, Oliveira MC, Stracieri AB, Moraes DA, Pieroni F, Barros GM, Madeira MI, Malmegrim KC, FossFreitas MC, Simoes BP, et al. 2009. C-peptide levels and insulin independence following autologous nonmyeloablative hematopoietic stem cell transplantation in newly diagnosed type 1 diabetes mellitus. JAMA 301: 15731579.

Craig RM, Traynor A, Oyama Y, Burt RK. 2003. Hematopoietic stem cell transplantation for severe Crohn's disease. Bone Marrow Transplant 32: S57-S59.

Crawford F, Stadinski B, Jin N, Michels A, Nakayama M, Pratt P, Marrack P, Eisenbarth G, Kappler JW. 2011. Specificity and detection of insulin-reactive $\mathrm{CD} 4^{+} \mathrm{T}$ cells in type 1 diabetes in the nonobese diabetic (NOD) mouse. Proc Natl Acad Sci 108: 16729-16734.

Daniel C, Sartory N, Zahn N, Geisslinger G, Radeke HH, Stein JM. 2007. FTY720 ameliorates Th1-mediated colitis in mice by directly affecting the functional activity of $\mathrm{CD} 4{ }^{+} \mathrm{CD} 25^{+}$regulatory T cells. J Immunol 178: 2458 2468.

De Groot AS, Moise L, McMurry JA, Wambre E, Van Overtvelt L, Moingeon P, Scott DW, Martin W. 2008. Activation of natural regulatory $\mathrm{T}$ cells by IgG Fc-derived peptide "Tregitopes." Blood 112: 3303-3311.

Delgoffe GM, Kole TP, Zheng Y, Zarek PE, Matthews KL, Xiao B, Worley PF, Kozma SC, Powell JD. 2009.
The mTOR kinase differentially regulates effector and regulatory $\mathrm{T}$ cell lineage commitment. Immunity 30: 832-844.

Delgoffe GM, Pollizzi KN, Waickman AT, Heikamp E, Meyers DJ, Horton MR, Xiao B, Worley PF, Powell JD. 2011. The kinase mTOR regulates the differentiation of helper T cells through the selective activation of signaling by mTORC1 and mTORC2. Nat Immunol 12: 295-303.

Dominguez-Villar M, Baecher-Allan CM, Hafler DA. 2011. Identification of $\mathrm{T}$ helper type 1-like, Foxp $3^{+}$regulatory $\mathrm{T}$ cells in human autoimmune disease. Nat Med 17: 673-675.

DPT-1-Diabetes-Study-Group. 2002. Effects of insulin in relatives of patients with type 1 diabetes mellitus. $N$ Engl J Med 346: 1685-1691.

Dubertret L, Sterry W, Bos JD, Chimenti S, Shumack S, Larsen CG, Shear NH, Papp KA, Group CMS. 2006. Clinical experience acquired with the efalizumab (Raptiva) (CLEAR) trial in patients with moderate-to-severe plaque psoriasis: Results from a phase III international randomized, placebo-controlled trial. Br J Dermatol 155: $170-181$.

Eagar TN, Karandikar NJ, Bluestone J, Miller SD. 2002. The role of CTLA-4 in induction and maintenance of peripheral T cell tolerance. Eur J Immunol 32: 972-981.

Edwards JC, Szczepanski L, Szechinski J, FilipowiczSosnowska A, Emery P, Close DR, Stevens RM, Shaw T. 2004. Efficacy of B-cell-targeted therapy with rituximab in patients with rheumatoid arthritis. $N$ Engl J Med 350: 2572-2581.

Ehrenstein MR, Evans JG, Singh A, Moore S, Warnes G, Isenberg DA, Mauri C. 2004. Compromised function of regulatory $\mathrm{T}$ cells in rheumatoid arthritis and reversal by anti-TNF $\alpha$ therapy. J Exp Med 200: 277-285.

Elias D, Cohen IR. 1996. The hsp60 peptide p277 arrests the autoimmune diabetes induced by the toxin streptozotocin. Diabetes 45: 1168-1172.

Elinav E, Adam N, Waks T, Eshhar Z. 2009. Amelioration of colitis by genetically engineered murine regulatory $\mathrm{T}$ cells redirected by antigen-specific chimeric receptor. Gastroenterology 136: 1721-1731.

Ephrem A, Chamat S, Miquel C, Fisson S, Mouthon L, Caligiuri G, Delignat S, Elluru S, Bayry J, LacroixDesmazes S, et al. 2008. Expansion of $\mathrm{CD} 4^{+} \mathrm{CD} 25^{+}$regulatory $\mathrm{T}$ cells by intravenous immunoglobulin: A critical factor in controlling experimental autoimmune encephalomyelitis. Blood 111: 715-722.

Farge D, Henegar C, Carmagnat M, Daneshpouy M, Marjanovic Z, Rabian C, Ilie D, Douay C, Mounier N, Clave E, et al. 2005. Analysis of immune reconstitution after autologous bone marrow transplantation in systemic sclerosis. Arthritis Rheum 52: 1555-1563.

Feng X, Kajigaya S, Solomou EE, Keyvanfar K, Xu X, Raghavachari N, Munson PJ, Herndon TM, Chen J, Young NS. 2008. Rabbit ATG but not horse ATG promotes expansion of functional $\mathrm{CD} 4{ }^{+} \mathrm{CD} 25^{\text {high }} \mathrm{FOXP}^{+}$ regulatory T cells in vitro. Blood 111: 3675-3683.

Fife BT, Bluestone JA. 2008. Control of peripheral T-cell tolerance and autoimmunity via the CTLA-4 and PD-1 pathways. Immunol Rev 224: 166-182. 
J.A. Bluestone and H. Bour-Jordan

Fife BT, Guleria I, Gubbels Bupp M, Eagar TN, Tang Q, Bour-Jordan $\mathrm{H}$, Yagita $\mathrm{H}$, Azuma M, Sayegh MH, Bluestone JA. 2006. Insulin-induced remission in newonset NOD mice is maintained by the PD-1-PD-L1 pathway. J Exp Med 203: 2737-2747.

Fife BT, Pauken KE, Eagar TN, Obu T, Wu J, Tang Q, Azuma M, Krummel MF, Bluestone JA. 2009. Interactions between PD-1 and PD-L1 promote tolerance by blocking the TCR-induced stop signal. Nat Immunol 10: $1185-1192$.

Fleming JO, Isaak A, Lee JE, Luzzio CC, Carrithers MD, Cook TD, Field AS, Boland J, Fabry Z. 2011. Probiotic helminth administration in relapsing-remitting multiple sclerosis: A phase 1 study. Multiple Sclerosis (Houndmills, Basingstoke, England) 17: 743-754.

Fontenot JD, Gavin MA, Rudensky AY. 2003. Foxp3 programs the development and function of $\mathrm{CD} 4^{+} \mathrm{CD} 25^{+}$ regulatory T cells. Nat Immunol 4: 330-336.

Ford C, Goodman AD, Johnson K, Kachuck N, Lindsey JW, Lisak R, Luzzio C, Myers L, Panitch H, Preiningerova J, et al. 2010. Continuous long-term immunomodulatory therapy in relapsing multiple sclerosis: Results from the 15-year analysis of the US prospective open-label study of glatiramer acetate. Multiple Sclerosis (Houndmills, Basingstoke, England) 16: 342-350.

Freedman MS, Bar-Or A, Oger J, Traboulsee A, Patry D, Young C, Olsson T, Li D, Hartung HP, Krantz M, et al. 2011. A phase III study evaluating the efficacy and safety of MBP8298 in secondary progressive MS. Neurology 77: 1551- 1560 .

Fridman JS, Scherle PA, Collins R, Burn TC, Li Y, Li J, Covington MB, Thomas B, Collier P, Favata MF, et al. 2010. Selective inhibition of JAK1 and JAK2 is efficacious in rodent models of arthritis: Preclinical characterization of INCB028050. J Immunol 184: 5298-5307.

Garren H, Robinson WH, Krasulova E, Havrdova E, Nadj C, Selmaj K, Losy J, Nadj I, Radue EW, Kidd BA, et al. 2008. Phase 2 trial of a DNA vaccine encoding myelin basic protein for multiple sclerosis. Ann Neurol 63: 611-620.

Genovese MC, Becker JC, Schiff M, Luggen M, Sherrer Y, Kremer J, Birbara C, Box J, Natarajan K, Nuamah I, et al. 2005. Abatacept for rheumatoid arthritis refractory to tumor necrosis factor $\alpha$ inhibition. N Engl J Med 353: 1114.

Goodnow CC, Sprent J, Fazekas de St Groth B, Vinuesa CG. 2005. Cellular and genetic mechanisms of self tolerance and autoimmunity. Nature 435: 590-597.

Goverman JM. 2011. Immune tolerance in multiple sclerosis. Immunol Rev 241: 228-240.

Govers C, Sebestyen Z, Coccoris M, Willemsen RA, Debets R. 2010. T cell receptor gene therapy: Strategies for optimizing transgenic TCR pairing. Trend Mol Med 16: 77-87.

Grewal IS, Flavell RA. 1996. The role of CD40 ligand in costimulation and T-cell activation. Immunol Rev 153: 85-106.

Guillot-Delost M, Cherai M, Hamel Y, Rosenzwajg M, Baillou C, Simonin G, Leclercq V, Mariotti-Ferrandiz ME, Six A, Bon-Durand V, et al. 2008. Clinical-grade preparation of human natural regulatory T-cells encoding the thymidine kinase suicide gene as a safety gene. J Gene Med 10: 834-846.
Hanidziar D, Koulmanda M. 2010. Inflammation and the balance of Treg and Th17 cells in transplant rejection and tolerance. Curr Opin Organ Transplant 15: 411-415.

Harry RA, Anderson AE, Isaacs JD, Hilkens CM. 2010. Generation and characterisation of therapeutic tolerogenic dendritic cells for rheumatoid arthritis. Ann Rheum Dis 69: $2042-2050$.

Hartung HP. 2009. New cases of progressive multifocal leukoencephalopathy after treatment with natalizumab. Lancet Neurol 8: 28-31.

Hauser SL, Waubant E, Arnold DL, Vollmer T, Antel J, Fox RJ, Bar-Or A, Panzara M, Sarkar N, Agarwal S, et al. 2008. Bcell depletion with rituximab in relapsing-remitting multiple sclerosis. $N$ Engl J Med 358: 676-688.

He XL, Radu C, Sidney J, Sette A, Ward ES, Garcia KC. 2002. Structural snapshot of aberrant antigen presentation linked to autoimmunity: The immunodominant epitope of MBP complexed with I-Au. Immunity 17: 83-94.

Herold KC, Hagopian W, Auger JA, Poumian-Ruiz E, Taylor L, Donaldson D, Gitelman SE, Harlan DM, Xu D, Zivin RA, et al. 2002. Anti-CD3 monoclonal antibody in new-onset type 1 diabetes mellitus. N Engl J Med 346: $1692-1698$.

Herold KC, Burton JB, Francois F, Poumian-Ruiz E, Glandt M, Bluestone JA. 2003. Activation of human T cells by FcR nonbinding anti-CD3 mAb, hOKT3 $\gamma 1$ (AlaAla). J Clin Invest 111: 409-418.

Herold KC, Gitelman S, Greenbaum C, Puck J, Hagopian W, Gottlieb P, Sayre P, Bianchine P, Wong E, SeyfertMargolis V, et al. 2009. Treatment of patients with new onset Type 1 diabetes with a single course of anti-CD3 $\mathrm{mAb}$ Teplizumab preserves insulin production for up to 5 years. Clin Immunol 132: 166-173.

Hilkens CM, Isaacs JD, Thomson AW. 2010. Development of dendritic cell-based immunotherapy for autoimmunity. Int Rev Immunol 29: 156-183.

Hu CY, Rodriguez-Pinto D, Du W, Ahuja A, Henegariu O, Wong FS, Shlomchik MJ, Wen L. 2007. Treatment with CD20-specific antibody prevents and reverses autoimmune diabetes in mice. J Clin Invest 117: 3857-3867.

Hu C, Du W, Zhang X, Wong FS, Wen L. 2012. The role of $\mathrm{Grl}^{+}$cells after anti-CD20 treatment in type 1 diabetes in nonobese diabetic mice. J Immunol 188: 294-301.

Illei GG, Cervera R, Burt RK, Doria A, Hiepe F, Jayne D, Pavletic S, Martin T, Marmont A, Saccardi R, et al. 2011. Current state and future directions of autologous hematopoietic stem cell transplantation in systemic lupus erythematosus. Ann Rheum Dis 70: 2071-2074.

Jacobson DL, Gange SJ, Rose NR, Graham NM. 1997. Epidemiology and estimated population burden of selected autoimmune diseases in the United States. Clin Immunol Immunopathol 84: 223-243.

Kappos L, Comi G, Panitch H, Oger J, Antel J, Conlon P, Steinman L. 2000. Induction of a non-encephalitogenic type $2 \mathrm{~T}$ helper-cell autoimmune response in multiple sclerosis after administration of an altered peptide ligand in a placebo-controlled, randomized phase II trial. The Altered Peptide Ligand in Relapsing MS Study Group. Nat Med 6: 1176-1182.

Kappos L, Radue EW, O'Connor P, Polman C, Hohlfeld R, Calabresi P, Selmaj K, Agoropoulou C, Leyk M, Zhang- 
Auberson L, et al. 2010. A placebo-controlled trial of oral fingolimod in relapsing multiple sclerosis. $N$ Engl J Med 362: $387-401$.

Karpus WJ, Kennedy KJ, Smith WS, Miller SD. 1996. Inhibition of relapsing experimental autoimmune encephalomyelitis in SJL mice by feeding the immunodominant PLP139-151 molecule. J Neurosci Res 45: $410-423$.

Karussis DM, Vourka-Karussis U, Lehmann D, Ovadia H, Mizrachi-Koll R, Ben-Nun A, Abramsky O, Slavin S. 1993. Prevention and reversal of adoptively transferred, chronic relapsing experimental autoimmune encephalomyelitis with a single high dose cytoreductive treatment followed by syngeneic bone marrow transplantation. $J$ Clin Invest 92: 765-772.

Kennedy KJ, Smith WS, Miller SD, Karpus WJ. 1997. Induction of antigen-specific tolerance for the treatment of ongoing, relapsing autoimmune encephalomyelitis: A comparison between oral and peripheral tolerance. J Immunol 159: 1036-1044.

Kessel A, Ammuri H, Peri R, Pavlotzky ER, Blank M, Shoenfeld Y, Toubi E. 2007. Intravenous immunoglobulin therapy affects $\mathrm{T}$ regulatory cells by increasing their suppressive function. J Immunol 179: 5571-5575.

Keymeulen B, Vandemeulebroucke E, Ziegler AG, Mathieu C, Kaufman L, Hale G, Gorus F, Goldman M, Walter M, Candon S, et al. 2005. Insulin needs after CD3antibody therapy in new-onset type 1 diabetes. $N$ Engl J Med 352: 2598-2608.

Kode JA, Mukherjee S, Joglekar MV, Hardikar AA. 2009. Mesenchymal stem cells: Immunobiology and role in immunomodulation and tissue regeneration. Cytotherapy 11: 377-391.

Kohm AP, Carpentier PA, Anger HA, Miller SD. 2002. Cutting edge: $\mathrm{CD} 4{ }^{+} \mathrm{CD} 25^{+}$regulatory T cells suppress antigen-specific autoreactive immune responses and central nervous system inflammation during active experimental autoimmune encephalomyelitis. J Immunol 169: 47124716.

Kohm AP, Williams JS, Bickford AL, McMahon JS, Chatenoud L, Bach JF, Bluestone JA, Miller SD. 2005. Treatment with nonmitogenic anti-CD3 monoclonal antibody induces $\mathrm{CD} 4^{+} \mathrm{T}$ cell unresponsiveness and functional reversal of established experimental autoimmune encephalomyelitis. J Immunol 174: 4525-4534.

Koulmanda M, Strom TB. 2010. T-cell-directed treatment strategies for Type 1 diabetes and the confounding role of inflammation. Immunotherapy 2: 431-436.

Latek RR, Suri A, Petzold SJ, Nelson CA, Kanagawa O, Unanue ER, Fremont DH. 2000. Structural basis of peptide binding and presentation by the type I diabetes-associated MHC class II molecule of NOD mice. Immunity 12: $699-710$.

Laughlin E, Burke G, Pugliese A, Falk B, Nepom G. 2008. Recurrence of autoreactive antigen-specific $\mathrm{CD} 4^{+} \mathrm{T}$ cells in autoimmune diabetes after pancreas transplantation. Clin Immunol 128: 23-30.

Law CL, Grewal IS. 2009. Therapeutic interventions targeting CD40L (CD154) and CD40: The opportunities and challenges. Adv Exp Med Biol 647: 8-36.

Lazar L, Ofan R, Weintrob N, Avron A, Tamir M, Elias D, Phillip M, Josefsberg Z. 2007. Heat-shock protein pep- tide DiaPep277 treatment in children with newly diagnosed type 1 diabetes: A randomised, double-blind phase II study. Diabetes Metab Res Rev 23: 286-291.

Levisetti MG, Suri A, Petzold SJ, Unanue ER. 2007. The insulin-specific $\mathrm{T}$ cells of nonobese diabetic mice recognize a weak MHC-binding segment in more than one form. J Immunol 178: 6051-6057.

Li Y, Huang Y, Lue J, Quandt JA, Martin R, Mariuzza RA. 2005. Structure of a human autoimmune TCR bound to a myelin basic protein self-peptide and a multiple sclerosisassociated MHC class II molecule. EMBO J 24: 2968 2979.

Liu W, Putnam AL, Xu-Yu Z, Szot GL, Lee MR, Zhu S, Gottlieb PA, Kapranov P, Gingeras TR, de St Groth BF, et al. 2006. CD127 expression inversely correlates with FoxP3 and suppressive function of human $\mathrm{CD} 4^{+} \mathrm{T}$ reg cells. J Exp Med 203: 1701-1711.

Long SA, Cerosaletti K, Bollyky PL, Tatum M, Shilling H, Zhang S, Zhang ZY, Pihoker C, Sanda S, Greenbaum C, et al. 2010. Defects in IL-2R signaling contribute to diminished maintenance of FOXP3 expression in $\mathrm{CD}^{+}$ $\mathrm{CD} 25^{+}$regulatory T-cells of type 1 diabetic subjects. $\mathrm{Di}$ abetes 59: 407-415.

Long SA, Rieck M, Sanda S, Bollyky JB, Samuels PL, Goland R, Ahman A, Rabinovitch A, Aggarwal S, Phippard D, et al. 2012. Rapamycin/IL-2 combination therapy in paitients with Type 1 diabetics augments Treg yet transiently impairs $\beta$ cell function. Diabetes 61: 2340-2348.

Lopez M, Clarkson MR, Albin M, Sayegh MH, Najafian N. 2006. A novel mechanism of action for anti-thymocyte globulin: Induction of CD $4^{+} \mathrm{CD} 25^{+} \mathrm{Foxp}^{+}{ }^{+}$regulatory T cells. J Am Soc Nephrol 17: 2844-2853.

Loschko J, Heink S, Hackl D, Dudziak D, Reindl W, Korn T, Krug AB. 2011. Antigen targeting to plasmacytoid dendritic cells via Siglec-H inhibits Th cell-dependent autoimmunity. J Immunol 187: 6346-6356.

Louvet C, Szot GL, Lang J, Lee MR, Martinier N, Bollag G, Zhu S, Weiss A, Bluestone JA. 2008. Tyrosine kinase inhibitors reverse type 1 diabetes in nonobese diabetic mice. Proc Natl Acad Sci 105: 18895-18900.

Ludvigsson J, Krisky D, Casas R, Battelino T, Castano L, Greening J, Kordonouri O, Otonkoski T, Pozzilli P, Robert JJ, et al. 2012. GAD65 antigen therapy in recently diagnosed type 1 diabetes mellitus. $N$ Engl J Med 366: $433-442$.

Machen J, Harnaha J, Lakomy R, Styche A, Trucco M, Giannoukakis N. 2004. Antisense oligonucleotides downregulating costimulation confer diabetes-preventive properties to nonobese diabetic mouse dendritic cells. J Immunol 173: 4331-4341.

MacMillan HF, Lee T, Issekutz AC. 2009. Intravenous immunoglobulin G-mediated inhibition of T-cell proliferation reflects an endogenous mechanism by which $\operatorname{IgG}$ modulates T-cell activation. Clin Immunol 132: 222-233.

Maier LM, Hafler DA. 2009. Autoimmunity risk alleles in costimulation pathways. Immunol Rev 229: 322-336.

Maki T, Gottschalk R, Ogawa N, Monaco AP. 2005. Prevention and cure of autoimmune diabetes in nonobese diabetic mice by continuous administration of FTY720. Transplantation 79: 1051-1055. 
J.A. Bluestone and H. Bour-Jordan

Malek TR, Yu A, Vincek V, Scibelli P, Kong L. 2002. CD4 regulatory $\mathrm{T}$ cells prevent lethal autoimmunity in IL2R $\beta$-deficient mice. Implications for the nonredundant function of IL-2. Immunity 17: 167-178.

Mandala S, Hajdu R, Bergstrom J, Quackenbush E, Xie J, Milligan J, Thornton R, Shei GJ, Card D, Keohane C, et al. 2002. Alteration of lymphocyte trafficking by sphingosine-1-phosphate receptor agonists. Science 296: 346349.

Maron R, Slavin AJ, Hoffmann E, Komagata Y, Weiner HL. 2002. Oral tolerance to copolymer 1 in myelin basic protein (MBP) TCR transgenic mice: Cross-reactivity with MBP-specific TCR and differential induction of anti-inflammatory cytokines. Int Immunol 14: 131-138.

Masteller EL, Warner MR, Tang Q, Tarbell KV, McDevitt H, Bluestone JA. 2005. Expansion of functional endogenous antigen-specific $\mathrm{CD} 4^{+} \mathrm{CD} 25^{+}$regulatory $\mathrm{T}$ cells from nonobese diabetic mice. J Immunol 175: 3053-3059.

Matloubian M, Lo CG, Cinamon G, Lesneski MJ, Xu Y, Brinkmann V, Allende ML, Proia RL, Cyster JG. 2004. Lymphocyte egress from thymus and peripheral lymphoid organs is dependent on S1P receptor 1. Nature 427: 355-360.

McClymont SA, Putnam AL, Lee MR, Esensten JH, Liu W, Hulme MA, Hoffmuller U, Baron U, Olek S, Bluestone JA, et al. 2011. Plasticity of human regulatory T cells in healthy subjects and patients with type 1 diabetes. J Immunol 186: 3918-3926.

McFarland HF, Martin R. 2007. Multiple sclerosis: A complicated picture of autoimmunity. Nat Immunol 8: 913919.

Merrill JT, Burgos-Vargas R, Westhovens R, Chalmers A, D’Cruz D, Wallace DJ, Bae SC, Sigal L, Becker JC, Kelly S, et al. 2010. The efficacy and safety of abatacept in patients with non-life-threatening manifestations of systemic lupus erythematosus: Results of a twelve-month, multicenter, exploratory, phase IIb, randomized, doubleblind, placebo-controlled trial. Arthritis Rheum 62: 3077.

Mohan JF, Levisetti MG, Calderon B, Herzog JW, Petzold SJ, Unanue ER. 2010. Unique autoreactive T cells recognize insulin peptides generated within the islets of Langerhans in autoimmune diabetes. Nat Immunol 11: 350-354.

Mohan JF, Petzold SJ, Unanue ER. 2011. Register shifting of an insulin peptide-MHC complex allows diabetogenic T cells to escape thymic deletion. J Exp Med 208: 23752383.

Monson NL, Cravens P, Hussain R, Harp CT, Cummings M, de Pilar Martin M, Ben LH, Do J, Lyons JA, Lovette-Racke A, et al. 2011. Rituximab therapy reduces organ-specific $\mathrm{T}$ cell responses and ameliorates experimental autoimmune encephalomyelitis. PloS ONE 6: e17103.

Monti P, Scirpoli M, Maffi P, Piemonti L, Secchi A, Bonifacio E, Roncarolo MG, Battaglia M. 2008. Rapamycin monotherapy in patients with type 1 diabetes modifies $\mathrm{CD}^{+} \mathrm{CD} 25^{+} \mathrm{FOXP}^{+}$regulatory T-cells. Diabetes 57: 2341-2347.

Mottet C, Uhlig HH, Powrie F. 2003. Cutting edge: Cure of colitis by $\mathrm{CD} 4{ }^{+} \mathrm{CD} 25^{+}$regulatory T cells. J Immunol 170: 3939-3943.

Muraro PA, Douek DC, Packer A, Chung K, Guenaga FJ, Cassiani-Ingoni R, Campbell C, Memon S, Nagle JW,
Hakim FT, et al. 2005. Thymic output generates a new and diverse TCR repertoire after autologous stem cell transplantation in multiple sclerosis patients. J Exp Med 201: 805-816.

Nadkarni S, Mauri C, Ehrenstein MR. 2007. Anti-TNF- $\alpha$ therapy induces a distinct regulatory $\mathrm{T}$ cell population in patients with rheumatoid arthritis via TGF- $\beta$. J Exp Med 204: 33-39.

Nanto-Salonen K, Kupila A, Simell S, Siljander H, Salonsaari T, Hekkala A, Korhonen S, Erkkola R, Sipila JI, Haavisto L, et al. 2008. Nasal insulin to prevent type 1 diabetes in children with HLA genotypes and autoantibodies conferring increased risk of disease: A double-blind, randomised controlled trial. Lancet 372: 1746-1755.

Nicholson LB, Kuchroo VK. 1997. T cell recognition of self and altered self antigens. Crit Rev Immunol 17: 449-462.

Nicholson LB, Greer JM, Sobel RA, Lees MB, Kuchroo VK. 1995. An altered peptide ligand mediates immune deviation and prevents autoimmune encephalomyelitis. Immunity 3: 397-405.

Nicolls MR, Gill RG. 2006. LFA-1 (CD11a) as a therapeutic target. Am J Transplant 6: 27-36.

Niens M, Grier AE, Marron M, Kay TW, Greiner DL, Serreze DV. 2011. Prevention of "Humanized" diabetogenic CD8 T-cell responses in HLA-transgenic NOD mice by a multipeptide coupled-cell approach. Diabetes 60: $1229-1236$.

Nimmerjahn F, Ravetch JV. 2008. Anti-inflammatory actions of intravenous immunoglobulin. Annu Rev Immunol 26: 513-533.

Ochando JC, Yopp AC, Yang Y, Garin A, Li Y, Boros P, Llodra J, Ding Y, Lira SA, Krieger NR, et al. 2005. Lymph node occupancy is required for the peripheral development of alloantigen-specific Foxp $3^{+}$regulatory T cells. J Immunol 174: 6993-7005.

Ochi H, Abraham M, Ishikawa H, Frenkel D, Yang K, Basso AS, Wu H, Chen ML, Gandhi R, Miller A, et al. 2006. Oral CD3-specific antibody suppresses autoimmune encephalomyelitis by inducing $\mathrm{CD} 4{ }^{+} \mathrm{CD} 25^{-}$ LAP $^{+}$T cells. Nov 12: 627-635.

Oh U, Blevins G, Griffith C, Richert N, Maric D, Lee CR, McFarland H, Jacobson S. 2009. Regulatory T cells are reduced during anti-CD25 antibody treatment of multiple sclerosis. Arch Neurol 66: 471-479.

Orban T, Bundy B, Becker DJ, DiMeglio LA, Gitelman SE, Goland R, Gottlieb PA, Greenbaum CJ, Marks JB, Monzavi R, et al. 2011. Co-stimulation modulation with abatacept in patients with recent-onset type 1 diabetes: A randomised, double-blind, placebo-controlled trial. Lancet 378: 412-419.

Oyama Y, Barr WG, Statkute L, Corbridge T, Gonda EA, Jovanovic B, Testori A, Burt RK. 2007. Autologous nonmyeloablative hematopoietic stem cell transplantation in patients with systemic sclerosis. Bone Marrow Transplant 40: 549-555.

Penaranda C, Tang Q, Ruddle NH, Bluestone JA. 2010. Prevention of diabetes by FTY720-mediated stabilization of peri-islet tertiary lymphoid organs. Diabetes 59: 14611468.

Penaranda C, Tang Q, Bluestone JA. 2011. Anti-CD3 therapy promotes tolerance by selectively depleting 
pathogenic cells while preserving regulatory $\mathrm{T}$ cells. $J$ Immunol 187: 2015-2022.

Pescovitz MD, Greenbaum CJ, Krause-Steinrauf $\mathrm{H}$, Becker DJ, Gitelman SE, Goland R, Gottlieb PA, Marks JB, McGee PF, Moran AM, et al. 2009. Rituximab, B-lymphocyte depletion, and preservation of $\beta$-cell function. N Engl J Med 361: 2143-2152.

Petzold C, Riewaldt J, Koenig T, Schallenberg S, Kretschmer K. 2010. Dendritic cell-targeted pancreatic $\beta$ cell antigen leads to conversion of self-reactive $\mathrm{CD} 4^{+} \mathrm{T}$ cells into regulatory $\mathrm{T}$ cells and promotes immunotolerance in NOD mice. Rev Diabet Stud 7: 47-61.

Punwani N, Scherle P, Flores R, Shi J, Liang J, Yeleswaram S, Levy R, Williams W, Gottlieb A. 2012. Preliminary clinical activity of a topical JAK1 $/ 2$ inhibitor in the treatment of psoriasis. J Am Acad Dermatol doi: org/10.1016/ j.jaad.2011.12.018.

Putnam AL, Brusko TM, Lee MR, Liu W, Szot GL, Ghosh T, Atkinson MA, Bluestone JA. 2009. Expansion of human regulatory T-cells from patients with type 1 diabetes. Diabetes 58: 652-662.

Rabinovitch A, Suarez-Pinzon WL, Shapiro AM, Rajotte RV, Power R. 2002. Combination therapy with sirolimus and interleukin-2 prevents spontaneous and recurrent autoimmune diabetes in NOD mice. Diabetes 51: 638 645.

Ransohoff RM. 2007. Natalizumab for multiple sclerosis. N Engl J Med 356: 2622-2629.

Raz I, Avron A, Tamir M, Metzger M, Symer L, Eldor R, Cohen IR, Elias D. 2007. Treatment of new-onset type 1 diabetes with peptide DiaPep277 is safe and associated with preserved $\beta$-cell function: Extension of a randomized, double-blind, phase II trial. Diabetes Metab Res Rev 23: $292-298$.

Rigby RJ, Vinuesa CG. 2008. SiLEncing SLE: The power and promise of small noncoding RNAs. Curr Opin Rheumatol 20: 526-531.

Roord ST, de Jager W, Boon L, Wulffraat N, Martens A, Prakken B, van Wijk F. 2008. Autologous bone marrow transplantation in autoimmune arthritis restores immune homeostasis through $\mathrm{CD} 44^{+} \mathrm{CD} 25^{+} \mathrm{Foxp}^{+}$regulatory T cells. Blood 111: 5233-5241.

Salomon B, Bluestone JA. 2001. Complexities of CD28/B7: CTLA-4 costimulatory pathways in autoimmunity and transplantation. Annu Rev Immunol 19: 225-252.

Salomon B, Lenschow DJ, Rhee L, Ashourian N, Singh B, Sharpe A, Bluestone JA. 2000. B7/CD28 costimulation is essential for the homeostasis of the $\mathrm{CD} 4{ }^{+} \mathrm{CD} 25^{+}$immunoregulatory $\mathrm{T}$ cells that control autoimmune diabetes. Immunity 12: 431-440.

Saudek F, Havrdova T, Boucek P, Karasova L, Novota P, Skibova J. 2004. Polyclonal anti-T-cell therapy for type 1 diabetes mellitus of recent onset. Rev Diabet Stud 1: $80-88$.

Sawicka E, Dubois G, Jarai G, Edwards M, Thomas M, Nicholls A, Albert R, Newson C, Brinkmann V, Walker C. 2005. The sphingosine 1-phosphate receptor agonist FTY720 differentially affects the sequestration of $\mathrm{CD}^{+} / \mathrm{CD} 25^{+}$T-regulatory cells and enhances their functional activity. J Immunol 175: 7973-7980.
Scalapino KJ, Daikh DI. 2008. CTLA-4: A key regulatory point in the control of autoimmune disease. Immunol Rev 223: 143-155.

Scalapino KJ, Tang Q, Bluestone JA, Bonyhadi ML, Daikh DI. 2006. Suppression of disease in New Zealand Black/New Zealand White lupus-prone mice by adoptive transfer of ex vivo expanded regulatory T cells. J Immunol 177: 1451-1459.

Schloot NC, Meierhoff G, Lengyel C, Vandorfi G, Takacs J, Panczel P, Barkai L, Madacsy L, Oroszlan T, Kovacs P, et al. 2007. Effect of heat shock protein peptide DiaPep277 on $\beta$-cell function in paediatric and adult patients with recent-onset diabetes mellitus type 1: Two prospective, randomized, double-blind phase II trials. Diabetes Metab Res Rev 23: 276-285.

Sfikakis PP. 2010. The first decade of biologic TNF antagonists in clinical practice: Lessons learned, unresolved issues and future directions. Curr Direct Autoimmun 11: $180-210$.

Simon G, Parker M, Ramiya V, Wasserfall C, Huang Y, Bresson D, Schwartz RF, Campbell-Thompson M, Tenace L, Brusko T, et al. 2008. Murine antithymocyte globulin therapy alters disease progression in NOD mice by a time-dependent induction of immunoregulation. Diabetes 57: 405-414.

Smith CE, Eagar TN, Strominger JL, Miller SD. 2005. Differential induction of IgE-mediated anaphylaxis after soluble vs. cell-bound tolerogenic peptide therapy of autoimmune encephalomyelitis. Proc Natl Acad Sci 102: 9595-9600.

Stadinski B, Kappler J, Eisenbarth GS. 2010a. Molecular targeting of islet autoantigens. Immunity 32: 446-456.

Stadinski BD, Delong T, Reisdorph N, Reisdorph R, Powell RL, Armstrong M, Piganelli JD, Barbour G, Bradley B, Crawford F, et al. 2010b. Chromogranin A is an autoantigen in type 1 diabetes. Nat Immunol 11: 225231.

Stadinski BD, Zhang L, Crawford F, Marrack P, Eisenbarth GS, Kappler JW. 2010c. Diabetogenic T cells recognize insulin bound to IAg7 in an unexpected, weakly binding register. Proc Natl Acad Sci 107: 10978-10983.

Steinman RM, Hawiger D, Nussenzweig MC. 2003. Tolerogenic dendritic cells. Annu Rev Immunol 21: 685-711.

Sugiyama H, McCormick TS, Cooper KD, Korman NJ. 2008. Alefacept in the treatment of psoriasis. Clin Dermatol 26: 503-508.

Tak PP, Rigby WF, Rubbert-Roth A, Peterfy CG, van Vollenhoven RF, Stohl W, Hessey E, Chen A, Tyrrell H, Shaw TM, et al. 2011. Inhibition of joint damage and improved clinical outcomes with rituximab plus methotrexate in early active rheumatoid arthritis: The IMAGE trial. Ann Rheum Dis 70: 39-46.

Tang Q, Bluestone JA. 2008. The Foxp3 ${ }^{+}$regulatory T cell: A jack of all trades, master of regulation. Nat Immunol 9: 239-244.

Tang Q, Henriksen KJ, Bi M, Finger EB, Szot G, Ye J, Masteller EL, McDevitt H, Bonyhadi M, Bluestone JA. 2004. In vitro-expanded antigen-specific regulatory $\mathrm{T}$ cells suppress autoimmune diabetes. J Exp Med 199: $1455-1465$.

Tang Q, Adams JY, Penaranda C, Melli K, Piaggio E, Sgouroudis E, Piccirillo CA, Salomon BL, Bluestone JA. 
J.A. Bluestone and H. Bour-Jordan

2008. Central role of defective interleukin-2 production in the triggering of islet autoimmune destruction. Immunity 28: 687.

Tao R, de Zoeten EF, Ozkaynak E, Chen C, Wang L, Porrett PM, Li B, Turka LA, Olson EN, Greene MI, et al. 2007. Deacetylase inhibition promotes the generation and function of regulatory T cells. Nat Med 13: 1299-1307.

Tarbell KV, Yamazaki S, Olson K, Toy P, Steinman RM. 2004. $\mathrm{CD} 25^{+} \mathrm{CD} 4^{+} \mathrm{T}$ cells, expanded with dendritic cells presenting a single autoantigenic peptide, suppress autoimmune diabetes. J Exp Med 199: 1467-1477.

Targan SR, Feagan BG, Fedorak RN, Lashner BA, Panaccione R, Present DH, Spehlmann ME, Rutgeerts PJ, Tulassay Z, Volfova M, et al. 2007. Natalizumab for the treatment of active Crohn's disease: Results of the ENCORE Trial. Gastroenterology 132: 1672-1683.

Tha-In T, Metselaar HJ, Bushell AR, Kwekkeboom J, Wood KJ. 2010. Intravenous immunoglobulins promote skin allograft acceptance by triggering functional activation of $\mathrm{CD} 4{ }^{+} \mathrm{Foxp}^{+}{ }^{+} \mathrm{T}$ cells. Transplantation 89: $1446-$ 1455.

Toubi E, Kessel A, Mahmudov Z, Hallas K, Rozenbaum M, Rosner I. 2005. Increased spontaneous apoptosis of $\mathrm{CD} 4{ }^{+} \mathrm{CD} 25^{+} \mathrm{T}$ cells in patients with active rheumatoid arthritis is reduced by infliximab. Ann NYAcad Sci 1051: 506-514.

Tsai S, Shameli A, Yamanouchi J, Clemente-Casares X, Wang J, Serra P, Yang Y, Medarova Z, Moore A, Santamaria P. 2010. Reversal of autoimmunity by boosting memory-like autoregulatory $\mathrm{T}$ cells. Immunity 32: 568-580.

Tyndall A. 2011. Successes and failures of stem cell transplantation in autoimmune diseases. Hematology 2011: $280-284$.

Tyndall A, Uccelli A. 2009. Multipotent mesenchymal stromal cells for autoimmune diseases: Teaching new dogs old tricks. Bone Marrow Transplant 43: 821-828.

van de Linde P, Tysma OM, Medema JP, Hale G, Waldmann H, Roelen DL, Roep BO. 2006. Mechanisms of antibody immunotherapy on clonal islet reactive T cells. Human Immunol 67: 264-273.

Vandenbark AA, Vainiene M, Ariail K, Miller SD, Offner H. 1996. Prevention and treatment of relapsing autoimmune encephalomyelitis with myelin peptide-coupled splenocytes. J Neurosci Res 45: 430-438.

Vendrame F, Pileggi A, Laughlin E, Allende G, MartinPagola A, Molano RD, Diamantopoulos S, Standifer N, Geubtner K, Falk BA, et al. 2010. Recurrence of type 1 diabetes after simultaneous pancreas-kidney transplantation, despite immunosuppression, is associated with autoantibodies and pathogenic autoreactive CD4 T-cells. Diabetes 59: 947-957.

Verburg RJ, Flierman R, Sont JK, Ponchel F, van Dreunen L, Levarht EW, Welling MM, Toes RE, Isaacs JD, van Laar JM. 2005. Outcome of intensive immunosuppression and autologous stem cell transplantation in patients with severe rheumatoid arthritis is associated with the composition of synovial T cell infiltration. Ann Rheum Dis 64: 1397-1405.

Waldron-Lynch F, Henegariu O, Deng S, PrestonHurlburt P, Tooley J, Flavell R, Herold KC. 2012. Teplizu- mab induces human gut-tropic regulatory cells in humanized mice and patients. Sci Trans Med 4: 118ra112.

Walter M, Philotheou A, Bonnici F, Ziegler AG, Jimenez R. 2009. No effect of the altered peptide ligand NBI-6024 on $\beta$-cell residual function and insulin needs in new-onset type 1 diabetes. Diabetes Care 32: 2036-2040.

Weaver DJ Jr, Liu B, Tisch R. 2001. Plasmid DNAs encoding insulin and glutamic acid decarboxylase 65 have distinct effects on the progression of autoimmune diabetes in nonobese diabetic mice. J Immunol 167: 586-592.

Webb M, Tham CS, Lin FF, Lariosa-Willingham K, Yu N, Hale J, Mandala S, Chun J, Rao TS. 2004. Sphingosine 1phosphate receptor agonists attenuate relapsing-remitting experimental autoimmune encephalitis in SJL mice. J Neuroimmunol 153: 108-121.

Wellcome Trust Case Control C. 2007. Genome-wide association study of 14,000 cases of seven common diseases and 3,000 shared controls. Nature 447: 661-678.

Wen Y, Ouyang J, Yang R, Chen J, Liu Y, Zhou X, Burt RK. 2008. Reversal of new-onset type 1 diabetes in mice by syngeneic bone marrow transplantation. Biochem Biophys Res Comm 374: 282-287.

Wherrett DK, Bundy B, Becker DJ, DiMeglio LA, Gitelman SE, Goland R, Gottlieb PA, Greenbaum CJ, Herold KC, Marks JB, et al. 2011. Antigen-based therapy with glutamic acid decarboxylase (GAD) vaccine in patients with recent-onset type 1 diabetes: A randomised double-blind trial. Lancet 378: 319-327.

Wicker LS, Todd JA, Peterson LB. 1995. Genetic control of autoimmune diabetes in the NOD mouse. Annu Rev Immunol 13: 179-200.

Wing K, Sakaguchi S. 2010. Regulatory T cells exert checks and balances on self tolerance and autoimmunity. Nat Immunol 11: 7-13.

Wolinsky JS, Narayana PA, O'Connor P, Coyle PK, Ford C, Johnson K, Miller A, Pardo L, Kadosh S, Ladkani D, et al. 2007. Glatiramer acetate in primary progressive multiple sclerosis: Results of a multinational, multicenter, double-blind, placebo-controlled trial. Ann Neurol 61: $14-24$

Woodle ES, Xu D, Zivin RA, Auger J, Charette J, O'Laughlin R, Peace D, Jollife LK, Haverty T, Bluestone JA, et al 1999. Phase I trial of a humanized, Fc receptor nonbinding OKT3 antibody, huOKT3 $\gamma 1$ (Ala-Ala) in the treatment of acute renal allograft rejection. Transplantation 68: $608-616$.

Wright GP, Notley CA, Xue SA, Bendle GM, Holler A, Schumacher TN, Ehrenstein MR, Stauss HJ. 2009. Adoptive therapy with redirected primary regulatory $\mathrm{T}$ cells results in antigen-specific suppression of arthritis. Proc Natl Acad Sci 106: 19078-19083.

Wynn D, Kaufman M, Montalban X, Vollmer T, Simon J, Elkins J, O’Neill G, Neyer L, Sheridan J, Wang C, et al. 2010. Daclizumab in active relapsing multiple sclerosis (CHOICE study): A phase 2, randomised, double-blind, placebo-controlled, add-on trial with interferon $\beta$. Lancet Neurol 9: 381-390.

Yopp AC, Krieger NR, Ochando JC, Bromberg JS. 2004. Therapeutic manipulation of $\mathrm{T}$ cell chemotaxis in transplantation. Curr Opin Immunol 16: 571-577.

Yoshida Y, Tsuji T, Fujita T, Kohno T. 2011. Relapse of experimental autoimmune encephalomyelitis after 
discontinuation of FTY720 (Fingolimod) treatment, but not after combination of FTY720 and pathogenic autoantigen. Biol Pharm Bull 34: 933-936.

Zand MS, Vo T, Huggins J, Felgar R, Liesveld J, Pellegrin T, Bozorgzadeh A, Sanz I, Briggs BJ. 2005. Polyclonal rabbit antithymocyte globulin triggers B-cell and plasma cell apoptosis by multiple pathways. Transplantation 79 : 1507-1515.
Zhang L, Nakayama M, Eisenbarth GS. 2008. Insulin as an autoantigen in NOD/human diabetes. Curr Opin Immunol 20: 111-118.

Zhou X, Bailey-Bucktrout SL, Jeker LT, Penaranda C, Martinez-Llordella M, Ashby M, Nakayama M, Rosenthal W, Bluestone JA. 2009. Instability of the transcription factor Foxp3 leads to the generation of pathogenic memory $\mathrm{T}$ cells in vivo. Nat Immunol 10: 1000-1007. 


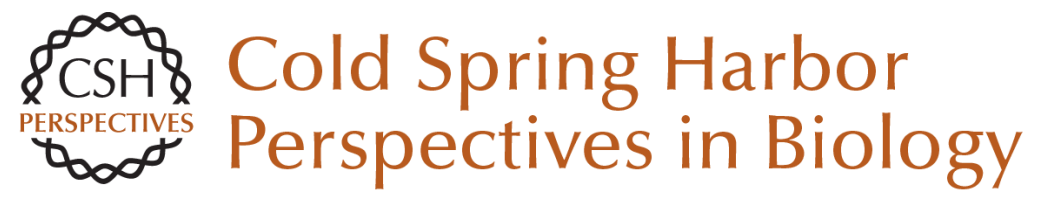

\section{Current and Future Immunomodulation Strategies to Restore Tolerance in Autoimmune Diseases}

Jeffrey A. Bluestone and Hélène Bour-Jordan

Cold Spring Harb Perspect Biol 2012; doi: 10.1101/cshperspect.a007542

Subject Collection Immune Tolerance

Regulatory T Cells and Immune Tolerance in the Intestine

Oliver J. Harrison and Fiona M. Powrie

Dendritic Cells: Arbiters of Immunity and Immunological Tolerance Kanako L. Lewis and Boris Reizis

Current and Future Immunomodulation Strategies

to Restore Tolerance in Autoimmune Diseases Jeffrey A. Bluestone and Hélène Bour-Jordan

T-Cell Tolerance: Central and Peripheral Yan Xing and Kristin A. Hogquist

Central B-Cell Tolerance: Where Selection Begins Roberta Pelanda and Raul M. Torres

The Immunogenetic Architecture of Autoimmune Disease

An Goris and Adrian Liston
Regulatory $\mathrm{T}$ Cells and Immune Tolerance in the Intestine

Oliver J. Harrison and Fiona M. Powrie

Microbiota and Autoimmunity

Alexander V. Chervonsky

Treg Cells, Life History, and Diversity Christophe Benoist and Diane Mathis

Infectious (Non)tolerance--Frustrated

Commensalism Gone Awry?

Jesse C. Nussbaum and Richard M. Locksley

Historical Overview of Immunological Tolerance Ronald H. Schwartz

Natural Killer Cell Tolerance: Control by Self or

Self-Control?

Baptiste N. Jaeger and Eric Vivier

For additional articles in this collection, see http://cshperspectives.cshlp.org/cgi/collection/

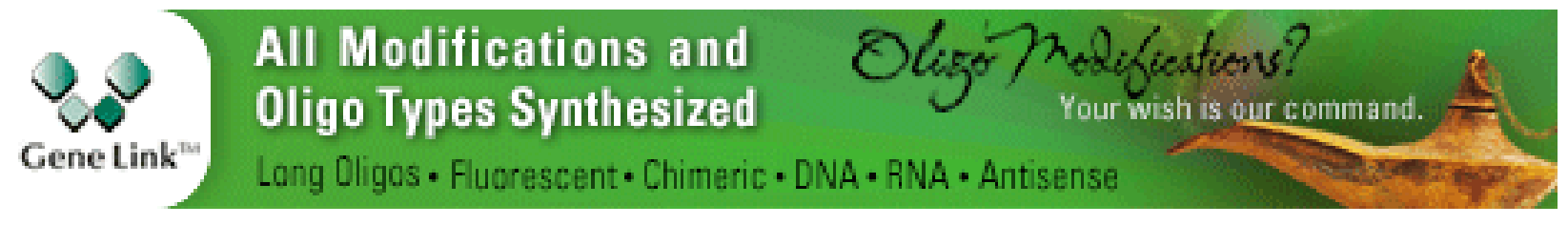

Copyright @ 2012 Cold Spring Harbor Laboratory Press; all rights reserved 